\title{
PROCEDURAL RIGHTS OF ALIENS BEFORE TRIBUNALS IN POLAND
}

\author{
LUDWIK KOS-RABCEWICZ-ZuBKOWSKI*
}

\section{INTRODUCTION}

With increased travel, greater internationalization of commerce, easier access to employment abroad, emigration, international aid, and fast, easy transportation and communications, there are now more occasions for conflicts between states, their nationals and aliens. Therefore, the question of access to local courts and the efficacy of remedies available in these courts is increasingly relevant.

Conflicts are now complicated by the increase in the number of claimants from different legal systems (civil law, common law, the law of socialist states, or others) and by the differing claims on judicial jurisdiction brought about by the recent growth of multinational or regional entities and courts and permanent arbitration bodies of an international type. This study describes the legal regime concerning civil and commercial relations of aliens in Poland.

\section{I}

\section{Access to Courts and Permanent Arbitration Bodies}

A. Code of Civil Procedure and International Agreements

The Polish Code of Civil Procedure of November I7, I $664{ }^{1}$ which came into force on January $1,1965,{ }^{2}$ contains the fundamental provisions on procedure before courts in Poland. Its third and last part (articles Iog6 to II53) deals with international civil procedure. The provisions of part three may be superseded by differing provisions of any international agreement to which the Polish People's Republic is a party. ${ }^{3}$

\section{B. Jurisdiction of Polish Courts ${ }^{4}$}

\section{General Conditions}

Polish courts may hear matters within their jurisdiction, as provided by the Polish Code of Civil Procedure, even in cases where such matters are already the subject of proceedings between the same parties before the courts of another state. ${ }^{5}$

\footnotetext{
* Professor of Law, University of Ottawa and Carleton University.

1 ig64 Dziennik Ustaw (Journal of Laws) No. 43, item 296 [hereinafter cited as Dz. U.]; rectification, $1965 \mathrm{Dz}$. U. No. 15, item Ix3.

${ }^{2}$ Art. I, Provisions Introducing the Code of Civil Procedure [hereinafter cited as C.P.], Law of Nov. I7, I964, 1964 Dz. U. No. 43 , item 297.

${ }^{3}$ Art. rog6 C.P.

- Rajski, Jurysdykcja krajowa a wlasciwosc sadow w sprawach cywilnych, 196r Panstwo I Prawo Nos. $4-5$, at $687-92$.

Art. тog8 C.P.
} 
The jurisdiction of Polish courts existing at the time of the institution of an action is maintained even if the reasons for such jurisdiction subsequently cease to exist. ${ }^{\circ}$ The courts will dismiss an action or motion ex officio if they consider that they have no jurisdiction in the matter in question. ${ }^{\text {? }}$

\section{Common Provisions for Adversary and Non-Adversary Proceedings}

Matrimonial causes are within the jurisdiction of Polish courts when at least one of the spouses is a Polish citizen or a stateless person residing in Poland. ${ }^{8}$ Should both spouses reside in Poland, Polish courts have exclusive jurisdiction. ${ }^{0}$ Matrimonial causes between aliens residing in Poland also lie within the jurisdiction of Polish courts. ${ }^{10}$ Similar provisions apply to the relations between parents and children or to the relations concerning adoption. ${ }^{11}$

Within the exclusive jurisdiction of Polish courts are real rights (in rem) and possession of immovables situated in Poland, matters resulting from the lease of such immovables (except claims as to rent) and all other matters related to immovables situated in Poland. ${ }^{12}$ Real rights (in rem) and possession of immovables situated outside Poland are not within the jurisdiction of Polish courts. ${ }^{13}$

The provisions of the Polish Code of Civil Procedure are not applicable when international bilateral treaties or multilateral conventions provide for differing rules. ${ }^{14}$ Poland is a party to numerous multilateral conventions, and among them are several elaborated by the Hague Conference on Private International Law as well as bilateral agreements on legal assistance and legal relations in civil, family and penal matters and bilateral consular agreements. ${ }^{15}$

\section{Adversary Proceedings}

Matters not mentioned in articles IroO, IIOI and Iro2 (the three articles forming title II, "Provisions common to adversary and non-adversary proceedings within the jurisdiction [of Polish courts]") and subject to adversary proceedings are within the jurisdiction of Polish courts under the following conditions: (a) when the defendant sojourns, resides or has his seat in Poland at the moment of the service of the action, (b) when the defendant has property or patrimonial rights in Poland, or (c) if the matter is related to a subject of litigation in Poland, to a succession opened in Poland or to an obligation formed or to be performed in Poland. ${ }^{16}$ Parties to a legal relation may agree in writing to submit to Polish courts present or future disputes which may result therefrom. ${ }^{17}$ A Polish unit of the socialized economy may agree in writing to exclude, in regard to its obligations, the jurisdiction of Polish courts in favor of courts of another state provided such an agreement is valid under the laws of the other state. This provision does not apply to the exclusive jurisdiction of Polish courts. ${ }^{18}$ Polish courts recognize agreements

\footnotetext{
'Art. 1097 C.P.

${ }^{\circ}$ Art. $x$ Iroo(2) C.P.

${ }^{12}$ Art. I102(I) C.P.

${ }^{7}$ Art. 1099 C.P.

${ }^{20}$ Art. I $100(3)$ C.P.

${ }^{13}$ Art. ITO2(2) C.P.

${ }^{s}$ Art. 1 roo(I) C.P.

${ }^{11}$ Art. rror (Y), (2), (3) C.P.

${ }^{14}$ Art. 1096 C.P.

${ }^{10}$ Art. 1103 C.P.

${ }^{17}$ Art. 1104 C.P.

${ }^{18}$ Art. $r 105(x)$ C.P.
} 
of the parties to submit to a foreign jurisdiction ${ }^{18}$ only if pleaded and proved by a party before pleading to the merits of the dispute. A Polish unit of socialized economy may also submit to an arbitration tribunal, functioning within or without Poland, any disputes on claiming patrimonial rights in the field of obligations. ${ }^{20}$

\section{Non-Adversary Proceedings}

The declaration for incompetence or of death of a Polish citizen or a stateless resident of Poland lies within Polish jurisdiction only. ${ }^{21}$ An alien may be declared dead by a Polish court when: (a) the person entitled to petition for the same resides in Poland, or (b) such an alien resides in Poland, or (c) his property is there. ${ }^{22}$ The recognition of death, when the death took place in Poland, lies with Polish jurisdiction only. ${ }^{23}$ Guardianship of a minor or curatorship of an incompetent who is a Polish citizen or a stateless person residing in Poland lie within Polish jurisdiction only. ${ }^{24}$ A Polish court may, however, refrain from appointing a guardian or curator for a Polish citizen residing or owning property outside Poland if it considers that the existing foreign guardianship or curatorship is sufficient. ${ }^{25}$ Polish courts may issue decisions in matters of guardianship and curatorship concerning an alien residing in or owning property in Poland, if they consider it in his interest to do so. ${ }^{26}$

Succession matters are within the jurisdiction of Polish courts when the deceased was a Polish citizen or a stateless person residing in Poland. ${ }^{27}$ Polish jurisdiction is exclusive when a Polish citizen dies in Poland. ${ }^{28}$ In cases of succession under Polish jurisdiction which was open abroad, the proper Polish court may declare the transmission of the estate following a motion by a Polish diplomatic or consular office. $^{29}$ All other non-adversary (non-contested) matters are within Polish jurisdiction when at least one party is a Polish citizen or resides in Poland or has his seat there. ${ }^{30}$

\section{Immunity from Jurisdiction and Execution}

The following aliens cannot be sued before Polish courts: (a) heads of diplomatic missions of other states accredited in Poland; (b) diplomatic personnel of such missions; (c) other persons having diplomatic immunity according to laws, treaties or universally established international customs; and (d) members of the families of all the above mentioned persons, if they are living with them. ${ }^{31}$ The foregoing

\footnotetext{
${ }^{10}$ Art. $1105(2)$ C.P.

${ }^{20}$ Art. I r05 (3) C.P. (I) and (2) are applied respectively.

${ }^{21}$ Art. $\operatorname{II06(I)}$ C.P.

24 Art. $I 107(x)$ C.P.

${ }^{22}$ Art. $1106(2)$ C.P. $\quad{ }^{23}$ Art. $1106(3)$ C.P.

${ }^{25}$ Art. $\operatorname{IIO}(2)$ C.P.

${ }^{20}$ Art. Iro7(3) C.P. Proceedings regarding guardianship are regulated by articles 590-98 C.P., and regarding curatorship by articles 599-605 C.P. The substantive provisions in these matters are in the Family and Guardianship Code of February 25, 1964 (1964 Dz. U. No. 9, item 59), in force on January I, 1965 (art. I, Law of Feb. 25, 1964, on the provisions introducing the Family and Guardianship Code) ( $x_{96}$ Dz. U. No. 9, item 60). Provisions on guardianship are in articles $145-74$, on curatorship in articles $175-84$.
27 Art. I I08(I) C.P.
${ }^{28}$ Art. $\operatorname{rIO} 8(2)$ C.P.
${ }^{31}$ Art. $\operatorname{IIII}(\mathrm{I})$ C.P.

${ }^{20}$ Art. I 109 C.P.

${ }^{30}$ Art. II Io C.P.
} 
provisions do not, however, apply to: (a) matters of real rights (in rem) concerning private immovables situated in Poland, unless they are owned on behalf of the state or international organizations represented by these persons; (b) successions where these persons are heirs, legatees, testamentary executors, administrators or curators of estates in their private capacity only and not on behalf of the state or international organization they represent; or (c) matters related to all kinds of professional or commercial activities undertaken by them in Poland besides their functions of office. ${ }^{32}$

An immunity from jurisdiction, limited to matters within the scope of activities exercised in execution of the functions of office, is granted to (a) officials of other (foreign) states exercising consular functions (regardless of their citizenship); and (b) aliens employed as administrative or technical employees by diplomatic missions or consular offices of foreign states in Poland, domestics of diplomatic missions and all other persons who enjoy the same status according to laws, treaties or universally established international customs. ${ }^{33}$

The foregoing provisions do not apply to actions in damages against officials exercising consular functions or to administrative and technical employees of consular offices when such damages are caused by a vehicle, a seagoing vessel or river craft or an airship..$^{34}$ Should a defendant acquire subsequent immunity to the institution of an action against him such an action shall be terminated by the court ex officio. ${ }^{35}$ The provisions of immunity do not apply when the foreign state or international organization renounces immunity for its officials. ${ }^{36}$ Should a person enjoying immunity start an action before a Polish court, the immunity shall not apply to counterclaims linked directly with the principal action. ${ }^{37}$ The provisions on immunity from jurisdiction are also applied to immunity from execution. ${ }^{38}$ The renunciation of the immunity from jurisdiction cannot be implied but must be made expressly. ${ }^{39}$ Even when execution is allowed it cannot be made against property used for official purposes or against the person of the debtor. ${ }^{40}$ Execution is inadmissible in the premises occupied by diplomatic representations, foreign missions, or consular offices of foreign states, or in the residences of diplomatic personnel unless with the consent of the head of the respective diplomatic representation, foreign mission, or consular office. ${ }^{41}$ In case of doubt as to the application of provisions on immunity courts shall request an opinion from the Minister of Justice. ${ }^{42}$

\section{Capacity of Aliens to Sue}

The capacity of aliens and stateless persons to sue is determined according to the provisions of the Polish Code of Civil Procedure. ${ }^{43}$ Any natural or legal person, or any social organization of working people duly allowed to act (the latter even when

\footnotetext{
${ }^{82}$ Art. IIII(2) C.P.

${ }^{35}$ Art. IIi3 C.P.

${ }^{38}$ Art. III5(I) C.P.

1 Art. III5(4) C.P.
}

${ }^{33}$ Art. $\operatorname{IIr}(1)$ C.P.
${ }^{38}$ Art. $\operatorname{III4}(1)$ \& (2) C.P.
${ }^{30}$ Art. $\operatorname{III5}(2)$ C.P.
${ }^{42}$ Art. $\operatorname{III6~C.P.~}$
${ }^{34}$ Art. $\operatorname{III2(2)}$ C.P.
${ }^{37}$ Art. III4(3) C.P.
${ }^{10}$ Art. III5(3) C.P.
${ }^{4}$ Art. III7 C.P. 
without a distinct legal personality), may be represented before Polish courts (zdolnosc sadowa).4 Natural persons limited in their rights to act must be represented by their legal representatives (for example by a guardian in the case of a minor or an incompetent $)^{45}$ except in those matters, if any, in which they may be allowed, by law, to act personally (zdolnosc procesowa).$^{46}$ Natural persons, their legal representatives in cases of limitation as to the right to act (minority, incompetence), and authorized employees of legal persons may act before Polish courts either personally or through their attorneys. ${ }^{47}$ The following persons may be appointed as attorneys: (a) an advocate, (b) a co-litigant, (c) an administrator of the property or interests of the party or his agent if the subject of litigation is within the scope of his powers, (d) parents, spouses, brothers and sisters, descendants or persons linked by adoption with the party. ${ }^{48}$ The power of attorney or its certified copy shall be filed with the first proceeding. An advocate or a legal counsel (which is a separate professional standing corresponding to the salaried government or corporate solicitor) may certify a copy of a power of attorney appointing them. In cases of doubt the court may request an official confirmation of the signature of a party. ${ }^{49}$ A power of attorney may also be given verbally by a party during a sitting of the court and entered into the minutes of the same. ${ }^{50}$ Under the condition of reciprocity, an advocate authorized to exercise his profession in the state of his principal's nationality may be admitted before a Polish court as the attorney of an alien. This applies also to stateless persons residing in such a state. ${ }^{51}$

\section{Security for Costs}

Upon the defendant's request a foreign plaintiff must deposit security for the costs of litigation. ${ }^{52}$ Security for costs is not required (a) when Polish citizens are not subject to the requirement of security for costs in the plaintiff's state; (b) when the plaintiff's residence is in Poland or he has property in Poland sufficient to guarantee the costs; (c) when he is entitled to an exemption or he has been excused from court costs; (d) in matrimonial non-patrimonial cases, as to counterclaims and in special proceedings before state notarial offices (in the latter case only if no protest is filed); (e) in cases submitted to Polish courts by the consent of parties. ${ }^{53}$ It should be noted that the reciprocity concerning liberation from the obligation to deposit security for costs does not depend upon the provisions of a treaty although it may in some cases, as the provisions of a treaty supersede the provisions of the Code of Civil Procedure..$^{54}$

The claim proceedings before state notarial offices ${ }^{55}$ may be in twofold form: (a) order proceedings (postepowanie nakazowe) ${ }^{56}$ and (b) claim proceedings (postepowanie upominawcze).$^{57}$ Order proceedings are used when proof of the plaintiff's

\footnotetext{
"Art. 64 C.P.

${ }^{47}$ Art. 86 C.P.

${ }^{50}$ Art. 89(2) C.P.

${ }^{50}$ Art. 66 C.P.

${ }^{48}$ Art. $87(\mathrm{I})$ C.P.

${ }^{63}$ Art. I 120 C.P.

${ }^{01}$ Art. $\operatorname{TII} 8$ C.P.

${ }^{48}$ Art. $65(2)$ C.P.

${ }^{40}$ Art. $89(\mathrm{I})$ C.P.

54 Art. 1096 C.P.

${ }^{62}$ Art. III9 C.P.

${ }^{5}$ Division V of Title VII on special proceedings, arts. $480-505$ C.P.

${ }^{50}$ Arts. $485-97$ C.P.

${ }^{57}$ Arts. 498-505 C.P.
} 
claim consists of official documents or private documents, the signature to which has been certified by an official public organ. ${ }^{58}$ Order proceedings are also used in cases of promissory notes, bills of exchange, and checks. ${ }^{50}$ The defendant is bound to pay the sum of money or deliver a quantity of things described in kind ${ }^{\text {d0 }}$ within one week after the service of the order issued by a state notarial office, or within the same time submit in writing the reasons for his non-payment. ${ }^{01} \mathrm{~A}$ counterclaim is not allowed. ${ }^{62}$ Compensation of claim may be made if proved by a document. ${ }^{03}$ Upon receipt of the reasons for non-payment (zarzuty) the state notarial office will refer the matter to the competent court. ${ }^{64}$ In order proceedings a foreign plaintiff is not required to deposit security for costs with the notarial state office. Such proceedings may be instituted against a foreigner even when he resides outside Poland as the Code of Civil Procedure does not exclude such a possibility. Claim proceedings, however, cannot be instituted against persons on whom service in Poland is impossible. ${ }^{65}$

Claim proceedings before state notarial offices may be instituted only for money claims not exceeding 2,000 zlotys (postepowanie upominawcze) ${ }^{60}$ Such proceedings do not apply to synallagmatic obligations. These proceedings, as mentioned earlier, cannot be instituted in cases where the service of the order cannot be made in Poland. ${ }^{67}$ Protests against the order to pay need not be supported by specific reasons and can even be made verbally and be entered into the minutes. ${ }^{68}$ While a person residing outside Poland cannot be ordered to pay according to the claim proceedings before state notarial offices, a foreigner may act as a plaintiff in such proceedings and he is not subject to the requirement of security for costs. ${ }^{09}$ In proceedings subject to the requirement of security for costs the defendant cannot request such security in cases where his partial recognition of plaintiff's claim is adequate to secure the costs. ${ }^{70}$

The defendant's request for security for costs shall be submitted, at the latest, at the time of his first proceedings. ${ }^{71}$ A late request is allowed only when the defendant learned subsequently that the plaintiff was a foreigner or when the grounds for the liberation of the plaintiff from the duty to deposit security for costs ceased at a later date. ${ }^{72}$ The court determines the amount of the security for costs, taking into account the probable costs of the defendant but not including the costs of a counterclaim. ${ }^{73}$ Should it appear at a later date that the security ordered was insufficient the defendant may request addditional security. ${ }^{74}$ The security for costs must be deposited in cash. ${ }^{75}$ This is a serious inconvenience, resulting in loss of interest on the money so deposited in Poland. Even worse is the requirement to convert the defendant's foreign currency into Polish currency in order to deposit it

\footnotetext{
${ }^{68}$ Art. ${ }_{485}$ C.P.

-1 Art. 49 I (I) C.P.

64 Art. 495 C.P.

${ }^{27}$ Art 499 C.P.

${ }^{70}$ Art. 1122 C.P.

${ }^{73}$ Art. II23(I) C.P.
}

${ }^{59}$ Art. 486 C.P.

${ }^{62}$ Art. 493 (I) C.P.

${ }^{65}$ Art. 499 (I), I 4, C.P.

${ }^{08}$ Art. 502 C.P.

71 Art. II III(I) C.P.

${ }^{75}$ Art. II23 (2) C.P.
${ }^{60}$ Art. 485 C.P.

${ }^{03}$ Art. 493 (2) C.P.

${ }^{\circ \theta}$ Art. 498 C.P.

${ }^{a 0}$ Art. XI20, 14 , C.P.

${ }^{72}$ Art. II2I(2) C.P.

${ }^{75}$ Art. II23(3) C.P. 
as security for costs. The Polish currency, zloty, is not a free currency. It cannot be transferred to Poland or brought to Poland, nor can it be taken out of Poland. It can be acquired only in Polish state banks and authorized state agencies. The rate of exchange is fixed by the Polish authorities, there being several rates of exchange depending on the type of transaction. The basic rate of exchange is four zlotys to one U.S. dollar; the tourist rate of exchange is 24 zlotys to one U.S. dollar. The rate of exchange available to persons wanting to purchase coupons, exchangeable for merchandise at the office of the Polish state enterprise P.K.O. is approximately 70 zlotys to one U.S. dollar, a rate which reflects the devaluation of the U.S. dollar. The rate of exchange on the so-called black market oscillates at around I0o zlotys for one U.S. dollar. This means that a foreign plaintiff may have to convert his state's currency, for example dollars, into Polish currency at an extremely adverse arbitrary rate of exchange. Any security for costs, when calculated in dollars, is therefore disproportionately high in comparison to the real value of the object of litigation. Should such a foreign plaintiff obtain a judgment in Poland in his favor he cannot reconvert the sum deposited as security for costs into his currency and have it transferred outside Poland, except by a special permit which may, or may not, be issued by the Polish National Bank ${ }^{76}$ (established by the decree of January 15, r945). ${ }^{77}$ The sum obtained in zlotys as the result of a judgment in Poland cannot be converted into a foreign currency and transferred outside Poland save by a special permit of the Polish National Bank. Except in cases of commercial transactions between non-Polish traders and Polish export-import state enterprises, permits for the transfer of sums from Poland are very rarely issued.

At the time of the application for the deposit of security for costs, the defendant is not bound to plead on the merits of the dispute. ${ }^{78}$ The court determines the deadline for the deposit of security. ${ }^{79}$ When the defendant fails to deposit the security within the established time limit, the court dismisses the action or appeal and decrees on costs as in the case of desistment from action. ${ }^{80}$ Should the grounds for the deposit of security for costs disappear during the course of litigation and following plaintiff's motion and hearing of the defendant, the court will free the plaintiff from the duty to deposit security for costs and order the reimbursement of the deposited security. ${ }^{81}$ When the court's decision is that costs should not be charged against the defendant, it will decree the reimbursement of the deposited security if the decision is not open to appeal, or, if it is, after the expiration of delays for appeal. ${ }^{82}$ The court will also decree the reimbursement of deposited security if, within one month after the decision becomes final, the defendant does not submit

\footnotetext{
${ }^{70}$ Art. 24 , Law of Dec. 2, I958, on the Polish National Bank (I958 Dz. U. No. 72, item 356), maintained in force by art. VIII(2), 113 , of the Law of Apr. 23, 1964, on the Introductory Provisions of the Civil Code (1964 Dz. U. No. 16, item 94), by art. IX, I5, of the Law of July 17, I964, on the Introductory Provisions on the Code of Civil Procedure ( 1964 Dz. U. No. 43, item 297), and by art. I69 of the Law of June 17, r966, on the Execution Procedure in Administration (State) (I966 Dz. U. No. 24, item 515).

77 I945 Dz. U. No. 4, item I4. ${ }^{78}$ Art. II24 (I) C.P.

${ }^{80}$ Art. 1124 (3) C.P.

${ }^{78}$ Art. $x \operatorname{I24}$ (I) C.P.
${ }^{81}$ Art. $x 125$ C.P.

${ }^{79}$ Art. II24(2) C.P.

${ }^{82}$ Art. Ir25(3) C.P.
} 
his motion for withdrawal from the said security of the sum necessary for payment of costs granted to him..$^{83}$ If the security is deposited by a foreigner, the defendant has the first claim for payment from the sum before all other creditors. ${ }^{84}$

The provisions on security for costs are applied also to non-adversary proceedings started on the motion of a foreigner. ${ }^{85}$ Poland is a party to the Hague Convention on Civil Procedure of July I7, I905. ${ }^{86}$ Its provisions are applicable to the territories of the signatory states, ${ }^{87}$ and they supersede the corresponding provisions of the Polish Code of Civil Procedure..$^{88}$ Chapter III of the Convention deals with the non-application of the requirement of security for costs (cautio judicatum solvi). Citizens of any of the states to the Convention, acting as plaintiffs or interveners before the court of another of these states, are not subject to security deposits or security for costs as they would otherwise be as foreigners or non-residents. ${ }^{80}$ The Convention states expressly that it does not modify provisions of treaties between the signatory states to this Convention insofar as such treaties provide for relief from the requirements of security for costs regardless of residence. ${ }^{00}$ Should a party, relieved of the duty to deposit security, be condemned to pay the costs of the litigation, then upon a request submitted through diplomatic channels the state of which he is a citizen will declare, free of charge, such decisions on costs executory in its territory. ${ }^{91}$

Any two signatories to this Convention may agree that a winning party should apply directly for enforcement of a decision on the payment of costs. ${ }^{92}$ The authority called upon to declare the decision enforceable may examine only whether the copy of the decision is authentic and whether it is executory in the country of origin. A corresponding declaration from the competent authority of the country of origin is sufficient evidence to satisfy these two conditions. The decision should be submitted in the language of the state where the enforcement is requested, or in a language agreed upon by the interested states or translated into one of these languages. In the absence of another agreement, it should be certified by a diplomatic or consular representative of the state requesting the enforcement or by a sworn translator of the state where enforcement is sought. ${ }^{93}$

Relief from the duty to deposit security for costs may be provided by reciprocity clauses in bilateral treaties. Thus the treaty on proceedings in civil and commercial matters between Great Britain and Poland, signed at Warsaw on August 26, r93r, ratified in London on May 2 $\pi$, 1932, provides that citizens of one contracting state, in residence there, are not subject to the requirements of security for costs if the same conditions apply to citizens of the other contracting state. ${ }^{94}$ This convention came into force as to relations between Poland and Canada on August I, r935, after

\footnotetext{
${ }^{83}$ Art. Ir26(2) C.P.

${ }^{84}$ Art. Ix27 C.P.

${ }^{88} 1926 \mathrm{Dz}$. U. No. 126, item 735.

${ }^{88}$ Art. Iog6 C.P.

${ }^{21}$ Art. 18.

${ }^{80}$ Art. I7.

${ }^{\circ}$ Art. 12.

${ }^{85}$ Art. 1128 C.P.

${ }^{90}$ Art. I7 in fine.

${ }^{93}$ Art. 19.

${ }^{92}$ Art. 18 in fine. ${ }^{87}$ Art. 26.
} 
an exchange of notes on July $\mathrm{I}$ and $23,1935 .^{95}$ Australia and New Zealand also adhered to this convention. The Hague Convention on Civil Procedure of March $\mathrm{r}$, 1954, was ratified by Poland in $1963^{96}$

The court costs payable to the treasury of the state are high in Poland, up to about five per cent of the value of the object in dispute. ${ }^{97}$ Until $\mathrm{rg} 6 \%$, court costs were regulated in Poland by the law of December 30, 1950, on court costs in civil matters. The law, which was divided into $\mathrm{II} 6$ articles, ${ }^{98}$ entered into force on January $x$, I95 ${ }^{, 99}$ and was maintained in force, except for article 3 , by the Code of Civil Procedure. ${ }^{100}$ The law on court costs was amended several times. ${ }^{101}$

Court costs in civil matters include court fees payable to the state and reimbursement of expenses to various persons. ${ }^{102}$ Expenses may consist of (a) telephone and telegraph costs; (b) travelling costs and per diem of judges, officials, and court employees acting outside the court building; (c) fees of witnesses, experts, and translators; (d) cost of transport, storage, and upkeep of persons, animals, and things; (e) costs of announcements in periodicals; $(f)$ dues payable to other authorities and officials; and (g) costs of any sojourn in detention. ${ }^{103}$ The amended text of the law on court costs was published on January 3 I, Ig6r. ${ }^{104}$ Of current importance is the fact that the original law was repealed by article 43 of the new law on court costs of June $13,196 \% .^{105}$ The decree of December 26, 1950, on the dues of witnesses, experts, and parties in court proceedings ${ }^{106}$ and the decree of the Minister of Justice of June 14,1960 , on sums payable to witnesses and parties in court proceedings $^{107}$ complete the law on court costs. The decree of the Minister of Justice of December 9, I948, deals with sworn translators ${ }^{108}$ as does his decree of December 9, I953. ${ }^{109}$

The remuneration of advocates is governed by the Minister of Justice's decree of April 22, I96r..$^{110}$ The dues of people's assessors (launicy), that is, lay judges sitting together with the presiding professional judge (the tribunal is composed of one professional judge and two assessors, each of the latter having the same right of vote as the professional judge), are regulated by the law of December 2, 1960, on people's assessors in courts of law. ${ }^{111}$

\footnotetext{
${ }^{D 5}$ According to art. $\mathrm{r7}$, r932 Dz. U. No. 55, item 533; I935 Dz. U. No. 70, item 44r; [1935] Can. T.S. No. 18.

${ }^{00}$ I963 Dz. U. No. $x 7$, item 91 .

${ }^{07}$ Przymusinski, The Commercial Laws of Poland, in The Digest of Commercial Laws of the WORLD 30 (I968).

${ }_{101}$ Decree of Mar. 4, I953, I953 Dz. U. No. 14, item 56; Decree of the Minister of Justice of Feb. 3, 1958, $195^{8} \mathrm{Dz}$. U. No. 13, item 56; Decree of the Minister of Justice of Jan. 7, 1958, 1958 Dz. U. No. 4, item I5; Law of May 28, I957, on Sale by the State of Residential Houses and Building Lots, I957 Dz. U. No. 31, item 132; Law of Mar. 28, 1958, on Changes of Civil Procedure, I958 Dz. U. No. I8, item 75. 102 Art. I, Law on Court Costs. 104 I96I Dz. U. No. Io, item 57.

${ }^{100} 1950$ Dz. U. No. 49 , item 445.

${ }^{108} 1948 \mathrm{Dz}$. U. No. 5I, item 256.

${ }^{110}$ I96r Dz. U. No. 24 , item II8.

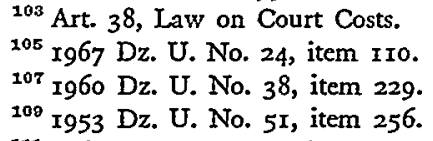




\section{E. Suits Against the Treasury of the State and Units of Socialized Economy}

Actions against the treasury of the state shall be instituted before the court which has jurisdiction in the place of the seat of the state organization concerned in the claim. ${ }^{112}$ Actions against those state enterprises and other state agencies that have separate legal personalities shall be instituted before the court that has jurisdiction in the place where such legal persons have their seats. ${ }^{113}$

A creditor having an executory title against the treasury of the state or against another state legal person (for example a final judgment after expiration of time for appeal, if any), does not need to apply for an enforcement clause. He files his executory title with the state organizational unit with which his claim is connected. The said unit is bound to pay the claim without delay. ${ }^{114}$ Should the treasury of the state or another state legal person (except state enterprises) fail to pay within one week from the filing of the executory title, the superior unit, following the creditor's motion, will order payment from the debtor's funds. ${ }^{115}$ In the case of failure to pay within one month on the part of a state enterprise, with the exception of the Polish State Railways and the Polish Post, Telegraph and Telephone, the creditor may proceed by a forced execution against the debtor's bank account but not against any other property of the debtor. ${ }^{118}$ When the debtor is a unit of the socialized economy but not a state organization, the execution of a money debt is made against its bank account. ${ }^{117}$ The latter provision applies mostly to cooperatives. Should the execution against a bank account prove fruitless after one month, such execution may be made against other property of the unit. ${ }^{118}$ Execution against permanent means of production may be made only when the execution against other property has failed.119 Execution against the bank accounts of agricultural production cooperatives is limited to one half of the active account, and, if this is insufficient, one half of each new deposit made in the future. ${ }^{120}$ Enforcement of non-money executory titles against state organizations is made by filing with the state organ in question. Should the latter fail to comply, the superior unit, upon creditor's motion, will order accordingly. ${ }^{121}$

\section{F. Arbitration With the Polish State Enterprises and Other Enterprises Engaged in International Trade}

\section{Code of Civil Procedure and Rules of Permanent Arbitral Bodies}

Arbitration is regulated by Book Three of the Code of Civil Procedure. ${ }^{122}$ The provisions of the Code are completed, but not changed, ${ }^{123}$ by the rules of permanent

\footnotetext{
112 Art. 29 C.P.

113 Art. 30 C.P.; J. Jodlowski \& W. Siedlecki, Postepowanie cywilne (czesc ogolna) (Civil Procedure [General Part]) 234 (I958). While the latter refers to the previous code of civil procedure, as amended, June 2, I954 (1954 Dz. U. No. 25, item 93), the corresponding provisions of both codes, the previous one and the one presently in force, are to the same effect.

${ }_{114}$ Art. 1060 C.P.

117 Art. $\operatorname{ro6}_{3}(\mathrm{I})$ C.P.

${ }^{180}$ Art. I06 4 C.P.

${ }^{115}$ Art. 106r C.P.

${ }^{118}$ Art. 1063 (2) C.P.

${ }^{121}$ Art. 1065 C.P.

${ }^{110}$ Art. 1062 C.P.

${ }^{210}$ Art. $\operatorname{xo6}_{3}$ (3) C.P.

${ }^{122}$ Arts. 695-715.

${ }^{123}$ J. Jakubowski, Permanent Arbitration Courts for Foreign Trade in Poland 5 (1962). See
} 
arbitration tribunals in Poland including (a) the Court of Arbitration at the Polish Chamber of Foreign Trade in Warsaw; (b) the International Court of Arbitration for Maritime and Inland Navigation in Gdynia; (c) the Gdynia Cotton Arbitration Chamber; and (d) the Gdynia Wool Arbitration Chamber. ${ }^{124}$ Polish parties may submit to arbitration disputes concerning property (patrimonial) interests, with the exception of alimony and labor relations. ${ }^{125}$ Polish state and socialized bodies, called in the Code "units of socialized economy," may submit to arbitration disputes with parties residing abroad or having their seat abroad (outside Poland) ${ }^{126}$ This right should not be confused with the obligation of such units of the socialized economy to submit to arbitration disputes among themselves. Polish courts have no jurisdiction in such matters, the State Arbitration Commission replacing law courts in this domain. ${ }^{127}$

In actual practice the vast majority of the international trade contracts of these Polish enterprises engaged in international trade with non-Polish traders contain arbitration clauses. ${ }^{128}$ Because of the state monopoly of foreign trade in Poland, ${ }^{129}$ such Polish enterprises are state corporations or, to a very limited extent, specially licensed unions of cooperatives.

\section{Court of Arbitration at the Polish Chamber of Foreign Trade}

The Court of Arbitration at the Polish Chamber of Foreign Trade was created in 1949 by a resolution of the Council of the Chamber of Foreign Trade, adopted according to the decree of September 28, I949, on the creation of the Polish Chamber of Foreign Trade. ${ }^{130}$ The Council of the Polish Chamber of Foreign Trade estab-

generally Kos-Rabeewicz-Zubkowski, Central and East European Rules on the Form of International Arbitration Agreements, 3 LA Revue JuRdique Thémis 415-48 (I968); Kos-Rabcewicz-Zubliowski, Le droit commercial international dans les rapports Est-Ousest, 5 CAN. Y.B. INT'L L. 159, 177-81 (I967); L. KosRabcewicz-Zubkowski, East European Rules on the Validity of INTERnational Commercial Arbitration Agreements (r97o) [hereinafter cited as East European Rules].

${ }^{124}$ Jakubowski, L'arbitrage commercial international en Pologne, 6 IL Diritro NegLi Scambi interNazionali No. 4, 566-67 (1967); Kos-Rabcewicz-Zubkowski, The Legal Aspects of Trade with Communist Countries in East-West Trade, The Canadian InstTtute of International Affatrs roz $f f$. (P. Uren ed. 1966).

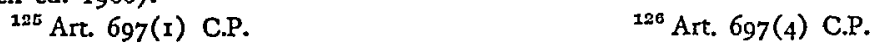

${ }^{197}$ Decree of Aug. 5, 1949, I949 Dz. U. No. 46, item 340, amended subsequently several times (amended text published in $1958 \mathrm{Dz}$. U. No. 29, item 132). This basic decree of the Council of Ministers is completed by several decrees issued at various dates by the Council of Ministers, by the Minister of Finance, by the Minister of Construction of Cities and Settlements, and by the Minister of Industrial Construction.

${ }^{128} \mathrm{~J}$. JARUBOWSKI, WAZNIEJSZE KLAUZULE KONTRAKTU KNUPA-SPRZEDAZY TOWAROW W HANDLU ZAgraniczmim (Important Clatses of the Contract of Sale in Foreign Trade) ir8 ff. (I964); L. OSIATYNSKI, KONTRAKT W HANDLU ZAGRANICZNYM, JEGO FORMULOWANIE I TEGHNIKA ZAWIERANIA-PROBiematyka prawna (Contract in Forejgn Trade, Its Formation and Technigue of NegotiationLegal Problems) 24 ( $I 964)$.

${ }^{120}$ Art. 7, I 2, of the Constitution of the Polish People's Republic of July 22, 1952, I952 Dz. U. No. 33 , item 232.

${ }^{130}$ Art. 5(14), I949 Dz. U. No. 53, ch. 403; art. I, Rules of the Court of Arbitration at the Polish Chamber of Foreign Trade. See generally Nanowski, L'Arbitrage commercial international, x966 Revuve de L'Arnitrage No. 4, at 78, 82; Jakubowski, Le Règlement des confits internationaux en matière économique en Pologne, ig66 Cariers de Droit Comparé No. I, at 144-47; J. Jakubowski, Permanent 
lished the rules of its Court of Arbitration. ${ }^{131}$ The seat of the Court is in Warsaw..$^{132}$ The court may settle disputes arising in connection with legal relations of a commercial character for both parties, or with the transport or insurance of goods, provided that at least one of the parties to the dispute is a natural or legal person having a permanent residence or seat (for legal persons) outside the territory of the Polish People's Republic. These conditions must exist on the day the court receives a petition for the opening of proceedings before the court. ${ }^{133}$ In order to confer jurisdiction on the Court of Arbitration, the arbitration agreement must be in writing, or the defendant must consent in writing to such jurisdiction after the plaintiff has filed a claim. Such jurisdiction may also result from an international (intergovernmental) agreement. ${ }^{134}$ There are no special formal requirements as to the type of written form. ${ }^{\mathbf{1 3 5}}$ The decision as to the jurisdiction of the Court is taken by the Presidium of the Court, ${ }^{136}$ composed of the President and three Deputy Presidents of the Court, appointed by the Council of the Polish Chamber of Foreign Trade. ${ }^{137}$ Thus such a decision is not taken by the chosen arbitrators.

Arbitrators appointed by the parties must be chosen from among the persons whose names are registered on the panel of arbitrators. ${ }^{138}$ The Council of the Polish Chamber of Foreign Trade makes the decision as to who will be registered and who will be stricken from the panel of arbitrators. ${ }^{139}$ The panel of arbitrators is maintained in the office of the Polish Chamber of Foreign Trade. ${ }^{140}$ Each party nominates from the panel of arbitrators an arbitrator or arbitrators in the number laid down by the arbitration agreement. If the agreement does not state otherwise, the arbitration tribunal shall be composed of three members, each of the parties concerned in the case appointing one arbitrator and the two arbitrators so ap-

Arbitration COURTs for Foreign Trade in Poland 13-26 (1962). The English translation of the rules of the Court of Arbitration at the Polish Chamber of Foreign Trade is reproduced in EAsr EuropEAN Rules I63-70.

${ }^{131}$ Art. I, Rules. The present rules entered into force on July I, I959.

132 Art. 2, Rules.

${ }^{133}$ Art. 12, Rules. See also Nanowski, supra note 130, at 82; Jakubowski, Le Règlement des conflits internationaux en matière économique en Pologne, 1966 CahIERs dE Drolt CoMparÉ No. I, at I44.

${ }^{134}$ Art. 13, Rules. Nanowski, supra note 130, at 13. J. Jakubowski, Permanent Armitration Counts for Foreign Trade in Poland 4 (I962). Trammer, Poland in Union Internationale des Avocats, 2 International Commercial ARBitration 137 (I960). International agrecments refer to arbitral permanent bodies disputes between the enterprises of the member states of the Council for Mutual Economic Assistance (COMECON). Bilateral similar agreements exist between Poland and Cuba, North Korea, North Vietnam, and the People's Republic of China. In contradistinction to the above treaties the agreements of the Polish Chamber of Foreign Trade with the American Arbitration Association, the Japan Commercial Arbitration Association, the Federation of Indian Chambers of Commerce and Industry, and the Associazione Italiana per l'Arbitrato cannot force the enterprises to submit to arbitration but tend only to facilitate such recourse. (For text as to Associazione Italiana per l'Arbitrato, see 1963 Rassegna deLL'Arbitrato No. 4 , at i76 f.)

${ }^{135}$ For a more detailed study, see EAsT European Rules. See also Kos-Rabcewicz-Zubkowsti, Central and East European Rules on the Form of International Commercial Arbitration Agreements, 3 LA REvuE JURIDIQUe THÉMIS 415-48 (x968).

${ }^{136}$ Art. 1o(4)(c), Rules; Nanowski, Zagadnienie mocy wiazacej klauzuli arbitrazowej ty praktyce kolegium arbitrow PIZH, I965 Prawo w HANDLU ZaGRANiczNYM No. 8, at 6o, case no. A $244 / 64$.
${ }_{137}$ Art. ro(2), Rules.
${ }^{138}$ Art. ${ }^{4}(3)$, Rules.
${ }^{130}$ Art. 6, Rules.

${ }^{140}$ Art. 8, Rules. 
pointed electing their chairman. ${ }^{141}$ Each party shall also appoint an alternate arbitrator. ${ }^{142}$ Should the chairman not be appointed by the parties and not be elected by the arbitrators within seven days, the president of the Court of Arbitration or his deputy shall make the appointment. ${ }^{143}$ The tribunal sits in Warsaw.

Upon motion by both parties, or ex officio, if it seems expedient, the Presidium of the Court of Arbitration may direct that the hearing shall take place elsewhere. ${ }^{144}$ The word may (in the Polish original moze) indicates that the Presidium is not bound by the motion of both parties and that it may refuse to hold the hearing outside Warsaw. The hearing shall be in the Polish language. The tribunal may, however, order the use of another language if expedient and if the parties do not object. ${ }^{145}$ The chairman of the tribunal shall appoint a translator when a party or his attorney do not speak the language in which the proceedings are conducted or when a party, a witness, or an expert declares that he cannot testify in the language in which the hearing is conducted. ${ }^{146}$ The hearings are public. ${ }^{147}$ Upon the motion of one of the parties ${ }^{148}$ or by order of the tribunal ex officio the hearing shall be in camera. ${ }^{149}$ Decisions are rendered by a majority of votes. ${ }^{150}$ Service is deemed sufficient when proved by a receipt. Should it be impossible or difficult to obtain such a receipt, service may be effected by registered mail. ${ }^{151}$ Following a motion by a party and at his cost, or following a decision by the tribunal ex officio, service may be carried out in another manner. ${ }^{152}$

The tribunal applies the law of the state that is most closely connected with the case in litigation, taking into consideration in the first place the intention of the parties, and furthermore, the principles of equity, good faith, and customs, in so far as this is permitted by the law applicable. ${ }^{153}$ The fee payable to the Polish Chamber of Foreign Trade is proportionate to the value in litigation. The minimum fee is $\mathrm{I}, 500$ zlotys in cases concerning amounts up to 50,000 zlotys. The maximum fee is I0,000 zlotys. ${ }^{154}$ Should the number of arbitrators be five or seven the fee is increased by fifty and one hundred per cent respectively. ${ }^{155}$ Should the litigation be heard by one arbitrator the fee is reduced by fifty per cent. ${ }^{156}$ In addition to the basic fee, parties pay all expenses (the travelling expenses of the arbitrators, officials, experts, translators, witnesses; remuneration of experts and translators; costs of transportation and storage of evidence; costs of announcements in periodicals; and dues payable to other courts and authorities). ${ }^{\mathbf{1 5 7}}$ Fees and expenses are paid by the party who requests the relevant proceeding. ${ }^{158}$ Should both parties request a proceeding, or in cases where it is ordered ex officio, both parties are

\footnotetext{
${ }^{141}$ Art. ${ }_{4}$ (3), Rules.

14 Art. 23(2), Rules.

${ }^{167}$ Art. 26(I), Rules.

${ }^{100}$ Art. 3 I (2), Rules.

${ }^{203}$ Art. 3 I (I), Rules.

${ }^{154}$ Art. 3(2), Tariff. The Tariff of Fees for the Functions of the Court of Arbitration at the Polish

Chamber of Foreign Trade is reproduced in EAsT EuropenN Rules 172-74.

${ }^{265}$ Art. 3(3), Tariff.

${ }^{208}$ Art. $x(2)$, Tariff.

132 Art. I4(4), Rules.

${ }^{1 * 5}$ Art. 25(I), Rules.

${ }^{148}$ Art. $26(2)$, Rules.

${ }^{152}$ Art. 32 (r), Rules.

${ }^{143}$ Art. $16(1)$, Rules.

140 Art. 25(2), Rules.

149 Art. 26(3), Rules.

${ }^{162}$ Art. 32(2), Rules.

${ }^{150}$ Art. 3(4), Tariff.

${ }_{187}$ Art. 6, Tariff.
} 
bound to pay in equal parts. ${ }^{159}$ There is no obligation to pay security for costs (cautio judicatum solvi).

A non-Polish party, in his writings to the Court of Arbitration, may use, besides Polish, English, French, German or Russian. ${ }^{160}$ The secretary of the court or the chairman of the arbitration tribunal may order the Polish party to furnish translations of his writings into one of the above mentioned languages. ${ }^{101}$ The defendant may file a counterclaim, if this falls within the jurisdiction of the Court of Arbitration. If there are no agreements to the contrary between the parties, any counterclaim shall be heard by the same tribunal that hears the original action. ${ }^{102}$ The awards of the Court of Arbitration are enforceable in Poland according to the Polish Code of Civil Procedure. ${ }^{163}$ If one of the parties does not comply with the award the Presidium of the Court of Arbitration, upon motion of the other party and with the consent of the tribunal which rendered the award, may order the communication of such non-compliance to other arbitration courts, stock exchange courts, or kindred institutions in Poland and outside Poland. The request for such sanctions may be submitted after the expiry of three months after the service of the award on the parties. The other party shall be informed about such a request. ${ }^{101}$

\section{International Court of Arbitration at Gdynia for Maritime and Inland Navigation}

The International Court of Arbitration at Gdynia for Maritime and Inland Navigation was established by the agreement of June I7, I959, between the Polish Chamber of Foreign Trade, the Chamber of Commerce of Czechoslovakia and the Chamber of Commerce of Foreign Trade of the German Democratic Republic (East Germany). ${ }^{105}$ The agreement is open to similar institutions of other states subject to the consent of the present parties. ${ }^{166}$

The Court of Arbitration for Maritime and Inland Navigation decides upon issues that may arise from maritime and inland navigation, in particular those arising from (a) charter parties and bills of lading, (b) contracts on handling of goods, (c) broker and forwarding contracts, (d) insurance policies, (e) collision of ships, and assistance, inasmuch as a sea-going or inland vessel is involved, ( $f$ ) salvage, (g) damages to port installations and equipment, $(\mathrm{h})$ general average. ${ }^{107}$ The court is not competent to deal with labor issues. ${ }^{108}$ The court will arbitrate if (a) the parties have so agreed in writing, (b) the plaintiff has filed his statement of claim and the defendant has agreed in writing to the court's jurisdiction, or (c) the jurisdiction of the court is laid down by an international treaty. ${ }^{100}$ The court sits in Gdynia. ${ }^{170}$ The parties may agree, however, that the venue be in Berlin,

\footnotetext{
${ }^{109}$ Art. I (3), Tariff.

102 Art. 22, Rules.

205 Nanowski, supra note 130 , at 88 .

${ }^{180}$ Art. 20(5), Rules.

${ }^{103}$ Art. 34, Rules.

101 Art. 20(5), Rulcs.

104 Art. 35, Rules.

${ }^{107}$ Art. $I(x)$ and (2), Rules of the International Court of Arbitration for Maritime and Inland Navigation in Gdynia, established on June I7, 1959. The English translation of the Rules is reproduced in EAst European Rules 174-83.

${ }^{108}$ Id. art. I (3), Rules.

${ }^{100}$ Id. art. 2, Rules.

${ }^{270}$ Id. art. $3(\mathrm{r})$, Rulcs.
} 
Prague or Warsaw. ${ }^{171}$ Upon the request of one of the parties and after hearing the other parties, the president of the court may order that the proceedings take place and the decision be made in another place. ${ }^{172}$ Arbitration commissions hearing disputes are composed of two arbitrators and one chairman. ${ }^{173}$ Each party appoints one arbitrator, who must be chosen from the persons entered by the Presiding Council of the court on the arbitrators' panel. ${ }^{174}$ The two appointed arbitrators elect their chairman. ${ }^{175}$ In the case of a party's failure to appoint an arbitrator, the president of the court appoints him for that party. ${ }^{178}$ If the arbitrators cannot agree within two weeks as to their chairman, the latter is also appointed by the president of the court. ${ }^{177}$ A person not entered on the panel of arbitrators may be appointed as chairman of an arbitration commission. Such a person must give notice, in writing, within a fixed period determined by the secretary of the court, that he accepts the office of the chairman and submits to the rules of the court. Otherwise the election is considered null and the arbitrators have to elect another person, this time chosen only from among the persons entered on the arbitration panel. ${ }^{178}$

Decisions are rendered by a majority (two arbitrators appointed from the persons on the panel of arbitrators can outvote their chairman). ${ }^{179}$ The defendant may submit a counterclaim. ${ }^{180}$ The arbitration commission applies the laws of the state most closely connected with the issue, taking into consideration the intention of the parties. It follows the principles of good faith and the commercial maritime and mariners' customs and usages concerning the issue, to the extent allowed by the applicable law. ${ }^{181}$ The party who initiates a proceeding is bound to pay the fees and a deposit for expenses. ${ }^{182}$ There is no obligation to deposit security for costs. Besides the fees payable to the court and proportionate to the value in litigation (the minimum fee is 1,500 zlotys; in cases where considerable amounts of money are involved it is twelve per cent of such value to a maximum of roo,ooo zlotys), there may be the following expenses: (a) travelling expenses and per diem of the arbitrators, officials of the court, experts, translators and witnesses; (b) experts and translators' fees; (c) transportation and storage costs of exhibits (evidence); (d) costs of publications; (e) fees payable by the court to other courts of authorities. ${ }^{183}$ Expenses must be reimbursed in the currency of the place of each hearing and each place of decision. ${ }^{184}$

\section{The Gdynia Cotton Arbitration Chamber}

The Gdynia Cotton Arbitration Chamber may hear disputes connected with sale contracts of cotton with a clause "Gdynia Rules" or "Arbitration in Gdynia" or a

\footnotetext{
${ }^{171}$ Id. art. $3(2)$, Rules.

${ }^{174}$ Id. art. 6, If a, Rules.

${ }^{172} I d$. art. $3(3)$, Rules.

${ }^{175} \mathrm{Id}$. art. $10(2)$, Rules.

${ }^{177}$ Id. art. I6(3), Rules.

${ }^{180}$ Id. art. $\mathrm{I9}(2)$, Rules.

${ }^{178}$ Id. art. 9(3), Rules.

${ }^{173}$ Id. art. 10, Rules.

${ }^{178} \mathrm{Id}$. art. I6(I), Rules.

${ }^{170}$ Id. art. 25 (I), Rules.

${ }^{181} I d$. art. 28, Rules.

${ }^{182}$ Id. art. I(2), Order of Costs. The English translation of the Order of Costs at the International Court of Arbitration for Marine and Inland Navigation at Gdynia is reproduced in EAsT EuropeaN RuLEs $181-83$.

${ }^{183}$ Id. art. $6(\mathrm{I})$, Order of Costs.

184 Id. art. 6(2), Order of Costs.
} 
similar clause to that effect. ${ }^{185}$ Chapter III of the Rules of the Gdynia Cotton Association, articles I to 40 , applies to arbitration, except in cases of disputes as to the quality of the cotton delivered, the latter arbitration being governed by special rules in chapter IV, articles $4 \mathrm{I}$ to II7. Under chapter III each party shall appoint this arbitrator who must be chosen only from among persons entered on the Association's panel of arbitrators. ${ }^{186}$ If legal questions are involved in the dispute, the arbitrators may apply to the Association's board of directors to refer the dispute to a state court of law; the decision of the board of directors is final and nonappealable. ${ }^{187}$ If the arbitrators decide that oral proceedings shall take place, they elect a third arbitrator-chairman. ${ }^{188}$ In cases of lack of agreement, the chairman is appointed by the President or executive Vice-president of the Association. ${ }^{180} \mathrm{~A}$ decision of the arbitrators is arrived at by a majority vote. ${ }^{190}$ Arbitrators apply the substantive law of the state most closely connected with the case in dispute, taking into consideration the intention of the parties and following the principles of good faith and the customs and usages prevailing in the cotton trade concerning the matter in dispute, so far as this is permitted by the applicable law. ${ }^{101}$ Rules are completed by provisions of the Polish Code of Civil Procedure. ${ }^{192}$

Within fourteen days from the date of the receipt of the award either party may appeal. ${ }^{193}$ The arbitrators in the second instance are appointed by the President or executive Vice-president of the Association. ${ }^{194}$ The decision in the second instance is final. ${ }^{195}$ In arbitration on quality, an appeal in respect of Sudan cotton and cotton waste is made to the Association; in respect of cotton of other origin, an appeal is made either to the Association or to the Chambre Arbitrale de Cotons S.A. in Le Havre (France). ${ }^{196}$

\section{The Court of Arbitration at the Gdynia Wool Federation}

The Court of Arbitration at the Gdynia Wool Federation may hear disputes "resulting from the sale in the international trade of wool and wool derivative raw products," 197 when its jurisdiction has been agreed upon by the parties in writing or if such jurisdiction has been provided for in international agreements. ${ }^{108}$ Each party shall appoint an arbitrator from among persons entered in the Court of Arbitration list of arbitrators. ${ }^{199}$ The arbitral tribunal shall decide, at its own discretion, upon the proposals as to evidence. ${ }^{200}$ In case of lack of agreement among the parties as to the appointment of the third arbitrator (the chairman of their

${ }^{185}$ Art. I, II General Rules, Rules of the Gdynia Cotton Association adopted by the 24th Ordinary General Assembly on June 4, r966, and in force on January $x, 1967$. The English translation of the "Rules of the Gdynia Cotton Association" is reproduced in EasT European Rules I83-207.
${ }^{186}$ Art. II, Rules.
${ }_{187}$ Art. ${ }_{4}$, Rules.
${ }^{188}$ Art. 19, Rules.
${ }^{180}$ Art. 22, Rules.
${ }^{102}$ Art. 27(b), Rules.
${ }^{190}$ Art. 19, Rules.
${ }^{103}$ Art. 28, Rules.
${ }^{101}$ Art. 27(a), Rules.
${ }^{105}$ Art. 39, Rules.
${ }^{104}$ Art. 3I, Rules.

${ }^{107}$ Section I, Rules of the Court of Arbitration at the Gdynia Wool Federation, adopted on December 15, 1966, at the General Assembly of the Gdynia Wool Federation. The English translation of the "Rules" is reproduced in EAST EuROpEAN Rules 306-r6.

${ }^{208}$ Id. $\$ 4$.

${ }^{198}$ Id. $\S 6(\mathrm{I})$.

${ }^{200}$ Id. $\$$ I4. 
arbitral tribunal), the President of the Wool Federation shall appoint such a chairman. $^{201}$ The provisions of the Polish Code of Civil Procedure may be applied to procedural questions not covered by the Rules of the Court of Arbitration. ${ }^{202}$

The arbitral tribunal shall apply the substantive laws of the state most closely connected with the case, taking into consideration the parties' will, and having regard also to the principles of good faith and commercial customs relating to the case in dispute and in current use in the trade of wool and of wool derivative products, to the extent permitted by the applicable law. ${ }^{203}$ Having regard in particular to the commercial customs, the arbitral tribunal may follow the principles accepted in agreements and in accordance with the Rules of the International Wool Textile Association. ${ }^{204}$ The request for arbitration as well as its enclosures may be drawn in one of the following languages: Polish, English, French, German or Russian. ${ }^{205}$ The Director of the Wool Federation or the arbitral tribunal may order a Polish party to submit its writings in one of these languages. If an arbitrator cannot perform his functions or if he causes a delay in the arbitration proceedings, then, upon the motion of a party or ex officio, the President of the Federation shall appoint another arbitrator and inform the parties thereof. ${ }^{206}$ Parties may be represented at hearings by proxies. ${ }^{207}$ No appeal is available from the award of the arbitral tribunal. ${ }^{208}$ The award has the same force as the judgment of a state court. ${ }^{209}$

II

\section{Problems Encountered by Aliens During the Process of Litigation as Platntiffs and Defendants}

\section{A. Suits in Forma Pauperis}

\section{Reciprocity}

Under the condition of reciprocity, aliens may be exempted from court costs according to the provisions of the Polish Code of Civil Procedure. ${ }^{210}$ Stateless persons residing in Poland are treated in the same way as Polish citizens. ${ }^{211}$ Poland is a party to the Hague Convention on Civil Procedure of July 17 , $1905 .^{212}$ Articles 20 to 23 (chapter IV) of this Convention deal with proceedings in forma pauperis. Citizens of any of the states party to this Convention are entitled to the right to proceed in forma pauperis in the other such states in the same way as citizens of those states. ${ }^{213}$ Attestations as to grounds for obtaining permission to act in forma pauperis are normally issued by the authorities of the place of residence of the party. ${ }^{214}$ Attestations, declarations, and information submitted to the granting authority are subject to examination by the latter. ${ }^{215}$ In cases of letters of request,

\footnotetext{
${ }^{201} I d . \$ 15$.

${ }^{204}$ Id. $\$ 20(2)$.

${ }^{202}$ Id. $\$ 20(3)$.

${ }^{207} \mathrm{Id} . \S \mathrm{I6}$.

${ }^{205} I d . \S 8(4)$.

${ }^{208}$ Id. $\$ 25(2)$.

${ }^{310}$ Art. $\operatorname{II29}(\mathrm{x})$ C.P.

${ }^{211}$ Art. $\operatorname{II29}(2)$ C.P.

${ }^{203} I d . \S 20(\mathrm{r})$.

${ }^{200} \mathrm{Id}$. § $\mathrm{I0}$.

${ }^{312} 1926 \mathrm{Dz}$. U. No. I26, ch. 735.

213 Art. 20.

${ }^{214}$ Art. $2 x$.

${ }^{215}$ Art. 22.
} 
however, the requesting state is bound to reimburse the executing state for the sums paid to witnesses and experts, ${ }^{216}$ the expenses caused by any special forms of service, ${ }^{217}$ and for any special forms of execution of the request. ${ }^{218}$

Proceedings in forma pauperis are also the subject of bilateral treaties. Thus the Convention on Proceedings in Civil and Commercial Matters between Great Britain and Poland, signed at Warsaw on August 26, I931, and ratified in London on May 3I, I932, provides that in matters of gratuitous judicial assistance, citizens of one of the contracting states will be treated in the territory of the other contracting state in the same manner as the citizens of that state. ${ }^{219}$ This Convention came into force between Poland and Canada on August I, I935, through the exchange of notes on July $\mathrm{I}$ and 23 , $1935 .{ }^{220}$ Australia and New Zealand also adhere to this Convention.

\section{Exoneration from Court Costs and Appointment of Free Local Counsel}

Exoneration from court costs may be granted to aliens by virtue of reciprocity or by the provisions of international treaties. In the absence of other provisions of treaties, the Polish Code of Civil Procedure applies. The following parties are exonerated from court costs: (a) plaintiffs in paternity suits and persons making claims resulting therefrom; (b) claimants of alimony; (c) plaintiffs claiming worker's (in Polish pracownika, which means manual workers and office employees alike) remuneration or damages resulting from an accident during working hours or from an illness contracted in following a particular profession; (d) state attorneys; (e) curators appointed by the court or by the guardianship court for a given matter; and $(f)$ parties exonerated from court costs by the court. ${ }^{221}$ In the absence of special provisions, costs due from the curator are temporarily charged to the party for whom the curator was appointed and, when this is impossible, to the party who appointed the curator. In the other cases mentioned above, court costs are provisionally charged to the state treasury. ${ }^{222}$ The court may exonerate a party from court costs entirely or partially. ${ }^{223}$

A natural person may petition for exoneration from costs by submitting a certificate from an organ of the state administration certifying that he cannot assume the costs without impairing the necessary support of himself and his family. Such a certificate shall describe in detail the properties and income of the party and give data on his family. The court will decide whether the certificate justifies the exoneration from costs. ${ }^{224} \mathrm{~A}$ juristic person and an unincorporated organization may be exonerated from costs if they prove that they do not possess sufficient means to bear costs. ${ }^{225}$ If in doubt, the court may order an appropriate investigation as to the 
financial situation of the party. ${ }^{226}$ In a case of obvious lack of grounds for action or defense, the court will not exonerate the party from costs. ${ }^{227}$ A party exonerated by the court from costs, either entirely or partially, may submit a motion for the appointment of an advocate to represent him. The court will grant the motion if it considers that an advocate is needed in the given matter. ${ }^{228}$ In this case, the court requests the local bar or advocates' collective to designate an advocate. A party exonerated from court costs by law may also apply for the appointment of an advocate. Such a party must submit a certificate issued by an organ of the state administration showing that he cannot pay advocate's fees without impairing his family's support. ${ }^{229}$ The court will withdraw the exoneration from costs and the right to appointment of an advocate when the grounds for the same cease to exist. ${ }^{230}$ The exoneration from costs and the appointment of an advocate do not exonerate a party from the duty to reimburse the costs of his adversary, according to the judgment in the case. ${ }^{231}$ The filing of a petition for exoneration from costs or for the appointment of an advocate does not stay the suit except when made in the plaintiff's statement of claim or before the filing of such a claim. However, the court may stay the examination of the case until a final decision has been made on such a petition. ${ }^{232}$ Remuneration of advocates for professional services is governed by the decree of the Minister of Justice of April 22, I96r. ${ }^{233}$

\section{B. International Judicial Cooperation}

In matters of international judicial cooperation Polish courts and state notarial offices $^{234}$ correspond with foreign courts and other foreign state organs as well as with Polish diplomatic missions and consular offices through the Ministry of Justice. $^{235}$ Polish courts grant legal assistance in response to requests of the courts and other organs of foreign states, ${ }^{236}$ except when (a) the requested proceeding would be contrary to the fundamental principles of the legal order of the Polish People's Republic or would infringe its sovereignty; (b) the requested proceeding is not within the sphere of action of the Polish courts; or (c) the state where the request originates refuses legal assistance to Polish courts. ${ }^{237}$ The request is executed according to Polish law. Should a foreign court or other organ of a foreign state request execution in a form different from that provided in Polish law, such a form may be followed if it is not specifically prohibited by Polish law and is not contrary to the fundamental principles of the legal order of the Polish People's Republic. ${ }^{238}$ Should a court or any other organ of a foreign state request a Polish court or a state notarial office to serve upon a person sojourning in Poland a writing in a language other than Polish, without a translation of the same into Polish, such

\footnotetext{
${ }^{220}$ Art. II6(I) C.P.

${ }^{20}$ Art. $x I 7(2)$ C.P.

${ }^{227}$ Art. II6(2) C.P.

${ }^{230}$ Art. 120 C.P.

${ }^{229}$ Art. $x I 7(I)$ C.P.

${ }^{232}$ Art. 124 C.P.

${ }^{238}$ I961 Dz. U. No. 24, item II8.

${ }^{284}$ State notarial offices are governed by the Law of May 25, I95I (I95I Dz. U. No. 36, item 276), * amended text of which was published on April 8, 1963 ( $x_{96} \mathrm{Dz}$. U. No. I9, item xo6).

${ }^{235}$ Art. II30 C.P.

${ }^{238}$ Art. $\operatorname{Ir} 32(1)$ C.P.

${ }^{237}$ Art. II3I(2) C.P.
} 
a writing will be delivered to the addressee if he will accept it. The addressee refusing to accept such a writing must be informed of the legal consequences which may result outside Poland concerning his refusal. ${ }^{239}$

Polish courts or state notarial offices may request assistance from Polish diplomatic missions, Polish consular offices, foreign courts, and other organs of a foreign state. ${ }^{240}$ The first two avenues are followed if the addressee or person requested to testify is a Polish citizen resident outside Poland, or if he is employed by a Polish diplomatic post, a Polish foreign mission, or a Polish consular office. ${ }^{241}$ When the addressee or witness is a non-Polish citizen, or when the performance of another proceeding is requested, the request is addressed to the proper foreign court or other state organ. ${ }^{242}$ This latter method is used in all cases where it is impossible to execute service or obtain evidence outside Poland through a Polish diplomatic mission or consular office. ${ }^{243}$ Service is carried out through the Ministry of Foreign Affairs upon persons sojourning in Poland but not subject to the jurisdiction of Polish courts or residing in buildings or apartments protected by immunity according to law, treaties or universally established international customs. ${ }^{24} \mathrm{~A}$ party to proceedings in Poland who is not represented by an attorney in Poland is bound to appoint an attorney for purposes of service. ${ }^{245}$ Should such a party fail to appoint an attorney for service, further service is done by filing the served proceedings in the record. At the time of the initial service, the party must be informed of the above procedure and also that he may reply in writing, and submit explanations in writing. He must also be informed as to whom he may appoint as his attorney. ${ }^{240}$ Details as to requests for judicial assistance are formulated in a decree of the Ministers of Justice and of Foreign Affairs. They may provide for means of communication other than through the Ministry of Justice. ${ }^{247}$ Evidence needed from outside Poland may be secured upon motion before the district court in Poland. ${ }^{248}$ Such a motion must be made before the court having the territorial jurisdiction in respect of the evidence in question. The motion must describe the petitioner and the respondent, indicate the facts and evidence and justify the need to secure such evidence. ${ }^{249}$ Evidence may be secured also before the institution of an action. ${ }^{200}$

Foreign official documents have the same force for purposes of proof in Poland as Polish official documents. However, documents concerning the transfer of immovable property situated in Poland must be legalized by a Polish diplomatic mission or by a Polish consular office. The same applies to any document of doubtful authenticity. ${ }^{251}$

Polish state notarial offices secure any assets of succession proceedings and open and probate testaments proceedings concerning estates left by foreigners outside the jurisdiction of Polish courts and state notarial offices. The consul of the state of

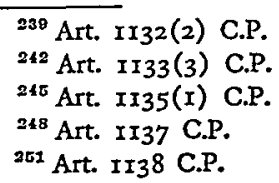

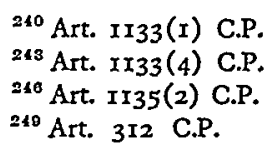


citizenship of de cujus is informed of the proceedings and may take part in the same. $^{252}$ Representatives of the deceased's state may, upon request, obtain a certified copy of the testament and the minutes of the opening and probate of the same. Under condition of reciprocity they may obtain the original of the testament if no other official proceedings in Poland are foreseen. ${ }^{253}$ The state notarial office will announce $e x$ officio that claimants to the estate must submit their claims and proof of the same within three months. ${ }^{254}$ The citizenship of de cujus must be mentioned in the announcement. A copy of such an announcement must be delivered to the proper financial administration office and to the proper consul. ${ }^{255}$ If no claims are submitted within the announced time limit, the estate is handed over to the proper consul. If claims have been submitted the court will hear the interested parties and decide as to the manner to secure their rights and their duties in this connection. That part of the estate which exceeds the value of such security will be handed over by the court to the proper consul, under the condition of reciprocity. ${ }^{256}$ While foreign heirs and legatees have the right to appeal the decision of the court in the first instance, in fact they cannot obtain their inheritance because of the impossibility of transferring funds from Poland to other countries without a permit of the Polish National Bank. In practice such permits are not granted in cases of inheritance by persons residing outside Poland. The state notarial office will secure objects left after a foreigner's death which occurs during a trip to Poland if he had no permanent residence there. If necessary, such objects are sold in order to cover the costs of the deceased's sojourn in Poland and of his funeral; the remainder is handed over to the proper consul. ${ }^{257}$

In cases where foreign law is applicable, Polish courts may request information from the Minister of Justice as to such foreign law and foreign court practices. ${ }^{258}$ The same applies to a statement regarding reciprocity. ${ }^{259}$ Courts may also request the opinion of other experts in these matters. ${ }^{260}$ Should the reasons for a Polish court's decision be needed for enforcement of such a decision outside Poland, the proper Polish court will prepare reasons, upon the motion of a party, a participant in the proceedings, or a person petitioning for enforcement of such decision. ${ }^{261}$

\section{III}

\section{Problems Encountered by Aliens in Obtaining Effective Remedies}

\section{A. Recognition of Foreign Judgments in Poland}

Recognition by Polish courts is superfluous for the final decisions (those which are non-appealable or for which the time limit for appeal expired and no appeal was lodged) of foreign courts in non-patrimonial matters concerning foreigners, if such decisions are rendered by proper courts according to lex patriae. Exceptions

\footnotetext{
${ }^{252}$ Art. $\mathrm{II} 39$ (I) C.P.

${ }^{305}$ Art. II $40(2)$ C.P.

${ }^{\text {s68 }}$ Art. II 43 (I) C.P.

${ }^{201}$ Art. II 44 C.P.
}

${ }^{253}$ Art. II39(2) C.P.
${ }^{260}$ Art. II4I(I) C.P.
${ }^{260}$ Art. II43 (2) C.P.
${ }^{254}$ Art. II40(I) C.P.

${ }^{257}$ Art. $I I 42$ C.P.

${ }^{260}$ Art. II 43 (3) C.P. 
occur when such decisions are the prerequisite for contracting marriage in Poland or for entry into the register of civil status (vital statistics) or land registration books or other registers in Poland. ${ }^{262}$ Decisions of foreign courts in civil matters, which, in Poland, are within the jurisdiction of the courts and are not subject to enforcement, are effective in Poland only when recognized by a Polish court. ${ }^{203}$ Under conditions of reciprocity, a foreign decision will be recognized in Poland if (a) the decision is final (no longer appealable) in the state where it was rendered; (b) the matter in question is not, according to Polish law or an international treaty to which Poland is a party, within the exclusive jurisdiction of Polish courts or courts of a third state; (c) the party has had an opportunity to defend himself, or, in the case of the lack of legal capacity to litigate, has had a proper representative appointed; (d) the matter in question was not already decided and subject to appeal by a Polish court, or an action before the proper Polish court was not instituted before the decision of a foreign court became final and non-appealable; (e) the decision is not contrary to the fundamental principles of legal order in the Polish People's Republic; or ( $f$ ) in the matter where Polish law is applicable, such Polish law is applied, unless the foreign law applied does not differ essentially from the Polish law. ${ }^{264}$ Conditions listed under items (d) and ( $f$ ) and the condition of reciprocity need not be met when the decision of a foreign court, in accordance with the rules of its state on jurisdiction and the law, states the acquisition by a person residing in Poland of an estate which at the time of the death of de cujus was in that court's jurisdiction. ${ }^{265}$

No reciprocity is required in matters which, according to Polish law, are within the exclusive jurisdiction of the state where the decision originated. ${ }^{280}$ The final non-appealable decisions of foreign courts in non-patrimonial matters concerning foreigners, rendered by the court having jurisdiction according to lex patriae, are denied recognition only in cases where they are contrary to the fundamental principles of legal order in the Polish People's Republic. ${ }^{267}$

Any interested party may apply for recognition of the decision of a foreign court. ${ }^{268}$ The petitioner must append to his motion for recognition (a) an official copy of the foreign decision; (b) a certified translation of the same into Polish; (c) a certificate that the decision is final and non-appealable; and furthermore, in the case of a judgment by default, (d) attestation that the writ of summons was duly delivered to the defendant. ${ }^{268} \mathrm{~A}$ decision on recognition is rendered by the provincial court (wojewodzki) having jurisdiction in this matter or within whose territorial jurisdiction the district court (powiatowy) having jurisdiction in this matter is located. The court sits as a bench of three professional judges. Otherwise the provisional court of Warsaw has jurisdiction. ${ }^{270}$ This is an exception, as normally the provincial court sits as a bench composed of one professional judge and two lay
${ }^{202}$ Art. II 45 (2) C.P.
${ }^{200}$ Art. II $46(2)$ C.P.
${ }^{263}$ Art. II 45 (I) C.P.
${ }^{300}$ Art. $1146(3)$ C.P.
${ }^{208}$ Art. Ir 47 (I) C.P.
${ }^{200}$ Art. $\operatorname{II} 47(2)$ C.P.

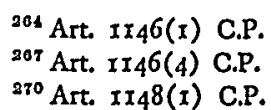


assessors, each of them having an equal vote. ${ }^{271}$ The attorney of the state participates in the recognition hearing. ${ }^{272}$

The decision on recognition is subject to revision. Should the time limit for revision expire, such decision is subject to a re-opening of proceedings (wznowienie postepowania). ${ }^{273}$ Revision is a normal appeal from the judgment of the first court. $^{274}$ The re-opening of proceedings may be decreed in certain cases, for example when a party was illegally deprived of the right to act, when he was not duly represented, ${ }^{275}$ and when the judgment was based on a falsified document or on a penal judgment subsequently quashed, or when the judgment was obtained through criminal action. ${ }^{276}$ As to final and non-appealable judgments of Polish courts recognizing foreign judgments on divorce, annulment of marriage, or declaration of the nonexistence of a marriage, if either one of the parties entered into a new marriage: (a) the leave for appeal after the expiry of the time limit for the same shall not be granted; ${ }^{277}$ (b) the re-opening of proceedings is inadmissible; ${ }^{278}$ and (c) the extraordinary revision is inadmissible. 279

\section{B. Enforcement in Poland of Foreign Judgments, of Settlements Made}

Before Foreign Courts, and of Arbitral Awards Rendered Outside Poland

The decisions of foreign courts in civil matters that are of the same type as those dealt with by courts in Poland, and which are of an enforceable type, will be enforced in Poland if so provided by an international treaty. In the absence of other provisions of the treaty, such decisions will be enforced in Poland if: (a) the decision was rendered after the entry into force of the international treaty in question; (b) the decision is enforceable in the state from which it originates; and (c) the conditions required for recognition of foreign judgments enumerated in article II46, paragraphs I to 6 of the Code of Civil Procedure ${ }^{280}$ were complied with. ${ }^{281}$ The same requirements apply to arbitral awards. ${ }^{282}$

Poland has ratified the following multilateral international conventions on arbitration: (a) Protocol on arbitral clauses of September 24, rg23; $^{283}$ (b) United Nations New York Convention on recognition and enforcement of foreign arbitral awards of June 6 , $195^{8 ; 284}$ and (c) Geneva European Convention on international commercial arbitration of April 2I, I96. ${ }^{285}$

Under conditions of reciprocity, Poland enforces the decisions of foreign courts granting alimony in cases resulting from family relations. In this case the enforcement in Poland will be granted even in absence of an applicable international treaty. ${ }^{286}$ The provincial court, having territorial jurisdiction in the place of

\footnotetext{
${ }^{271}$ Art. 47 C.P.

374 Arts. $367-93$ C.P.

${ }^{277}$ Arts, II 49 \& I70 C.P.

${ }^{280}$ Art. Ir 46 (I) C.P.

${ }^{272}$ Art. $1148(2)$ C.P.

${ }^{275}$ Art. 401 C.P.

${ }^{278}$ Arts. II 49 \& 400 C.P.

${ }^{281}$ Art. 1150 (I) C.P.

${ }^{283} 27$ L.N.T.S. I57; I93I Dz. U. No. 84 , item 648 .

284330 U.N.T.S. 3 ; 1962 Dz. U. No. 9, items $41-42$.

${ }_{285}{ }_{484}$ U.N.T.S. $349 ; 1964$ Dz. U. No. 40 , items $270-7 x$.

${ }^{386}$ Art. II 50 (3) C.P.
}

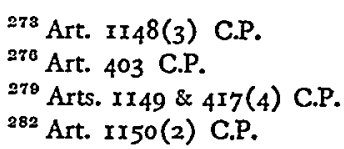



The prohibition on transfers of foreign currencies, of Polish currency, and gold and platinum (if not in jewelry or the like) are sanctioned by imprisonment of up to five years and by fines ranging from too to $1,000,000$ zlotys. ${ }^{298}$ Furthermore, all patrimonial rights of the offender may be confiscated, as well as the property involved in the offense. ${ }^{297}$ These are extremely harsh provisions. The Polish Supreme Court reasoned that the penal provisions in this matter are not only to protect the national patrimony, but, more importantly, to protect the interests of the state in the trade (sensu largo) of values payable in non-Polish currency. ${ }^{298}$ The offenses under the rg60 penal treasury law are construed as being of an objective type, that is, they are considered as having been committed even when the offender acted without the requisite intent to do wrong (no mens rea or dolus malus). Thus these offenses are subject to sanctions whether committed intentionally or unintentionally. ${ }^{299}$ Article 4 of the 1960 law is written in such broad terms that a literal interpretation of it would make a foreigner liable to sanctions in Poland if, for example, he exchanged foreign currency outside Poland at a rate differing from that prescribed by the Polish National Bank. ${ }^{300}$ This would obviously be absurd. Thus Hochberg considers that the sanctions apply only to commerce between a person resident in Poland and a party resident outside Poland, as specified in article $\mathrm{I}$ of the currency control law of $195^{2 .{ }^{301}}$ Since $195^{6}$ the possession, but not the sale or exchange, of foreign currencies, and gold and platinum is allowed in Poland..$^{302}$

Offenses sanctioned by fines only are within the jurisdiction of the finance departments of provincial national councils (wydzialy finansowe wojewodzkich rad narodowych) or, in cases of transportation through state boundaries, within the jurisdiction of customs offices indicated by the Minister of Foreign Trade. ${ }^{303}$ The convicted offender may appeal either to the Ministry of Finance or to the Central Administration of Customs, or to courts of general jurisdiction. ${ }^{304}$ Offenses sanctioned by imprisonment are within the jurisdiction of the district court sitting without lay assessors, unless the president of the court decides that the case may be heard by one professional judge with two lay assessors. ${ }^{305}$ The provincial court acts in appeal, one professional judge sitting in such cases, unless, because of the complexity of the case, the president of the court decides that it should be heard by three judges. ${ }^{308}$

The use of currency and currency values such as bills of exchange, checks, letters of credit, and money orders in foreign trade requires a permit from the Minister

\footnotetext{
200 Art. 49.

${ }^{207}$ Arts. 25(I) d \& e, (5), (6), \& 62.

${ }^{208}$ Judgment of Oct. 5, I959, No. I K 502/58, quoted by Hochberg, Przestepstwa dewizowe w nowej ustawie karnej skarbowej (Ctmency Offenses in the New Penal Treasury Law), ig6o Panstwo I Prawo Nos. 8.9, at 303 n.3.

${ }^{200}$ Hochberg, supra note 298 , at 304 .

${ }^{301}$ Hochberg, supra note 298 , at 305.

${ }^{800}$ Art. 6r(I), Penal Treasury Law.

${ }^{302}$ Decree of the Minister of Finance of Nov. $7, x 956, x 956 \mathrm{Dz}$. U. No. 50, item 223, II, modify-

ing 133 of the Decree of Apr. I5, I952, I952 Dz. U. No. 21, item I37.

${ }^{203}$ Arts. II4 \& 124 , Penal Treasury Law.

${ }^{805}$ Art. 22I, Penal Treasury Law.

${ }^{804}$ Art. $x 84$, Penal Treasury Law.

${ }^{806}$ Art. 222, Penal Treasury Law.
} 
of Foreign Trade where Polish parties are involved. ${ }^{307}$ All payments involving foreign parties must be made through the Polish National Bank. ${ }^{808}$ In addition, the compensation of payments to foreign parties requires a permit. ${ }^{300}$ Within thirty days of the acquisition of property rights abroad, they must be declared in Poland by the owner. ${ }^{310}$ The same applies to obligations toward foreigners and foreign property in Poland. ${ }^{311}$

IV

\section{Spectal Problems Encountered by Both Alien and National Litugants}

\section{A. Legislative and Administrative Measures on Expropriation and Limitation of Ownership Rights}

Administrative limitations on the use of property apply both to aliens and nationals. Thus, for example, the choice of tenants and the rate of rent for leased premises in private buildings is withdrawn from the owners and vested instead in the state authorities. ${ }^{312}$ Nationalization of landed property exceeding fifty hectares of cultivated agricultural land was decreed on September $6,1944,{ }^{313}$ by the Polish Committee of National Liberation, a self-appointed communist group. The nationalization of land within these limits and of mineral resources, waters, most forests, mines, roads, railways, water and air transportation, communications media, banks, industrial establishments (save small workshops), and of more important commercial enterprises was the subject of numerous legislative and administrative texts, according to the principle classifying these categories as national property embodied in the constitution of the Polish People's Republic of July 22, 1952..$^{314}$ A token indemnification, if any, was foreseen for the owners of nationalized property. In practice the owners had to bear the losses.

\section{B. Rules of Evidence}

The semi-inquisitorial character of rules of evidence in the Polish procedure differs from that of the basic adversary system in force in common law countries. Facts admitted by the adversary do not need proof unless they create doubt as to their conformity with the true state of things. ${ }^{315}$ When one party does not express an opinion as to the allegations of the other party, the court, taking into consideration the submitted evidence in its entirety, may consider such uncontested allega-

\footnotetext{
${ }^{307}$ Art. 19, Law of Mar. 28, 1952, 1952 Dz. U. No. 21, item r33.

${ }^{30}$ Art. I2, Decree of the Minister of Finance of Apr. 15, I952, on Execution of the Law on Currencies, $x 952$ Dz. U. No. 21 , item 137 .

$309 \mathrm{Id}$.

${ }^{310}$ Art. 3, Decree of the Minister of Finance of Apr. 15, 1952, on Declaration of Property Rights Abroad, I952 Dz. U. No. 21, item 138.

${ }^{811}$ Decree of the Minister of Finance of Apr. 15, 1952, on Declaration of Obligations Towards Foreigners and Foreign Property in Poland, 1952 Dz. U. No. 21, item 139.

${ }^{312}$ Decree of the Council of Ministers of July 20, 1965, on Rents for Living Quarters, I965 Dz. U. No. 35, item 224; Law on Accommodations of Jan. 30, x959, 1959 Dz. U. No. xo, item 59, amended text, 1962 Dz. U. No. 47 , item 227.

${ }^{318} 1944$ Dz. U. No. 3, item 17. Art. 2 of the amended text, 1945 Dz. U. No. 3, item I3.

814 r952 Dz. U. No. 33, item 233.

${ }^{325}$ Art. 229 C.P.
} 
tions of fact as admitted. ${ }^{316}$ The parties are required to provide the evidence needed for a decision on the dispute. The court may, however, admit evidence not supplied by the parties. The court may also order an investigation to provide necessary evidence. $^{317}$

There are no provisions on hearsay in Poland. When the law or the contract between the parties requires that it be in writing, evidence is admitted both by witnesses or parties regarding such a written instrument only when the instrument is lost, destroyed, or taken by a third person. In cases where the written form is required for evidence purposes only, and not for the validity of the act, evidence by witnesses or parties may be admitted as specified in the Civil Code. ${ }^{318}$ When a law states that specific action must be memorialized in written form, failure to use the written form does not invalidate the action unless the law states explicitly that lack of written form nullifies such an action. ${ }^{319}$ When the requirement of the written form is not sanctioned by nullity of action undertaken by a party, it means that evidence by witnesses or by hearing of the parties is inadmissible. Such evidence is permitted, however, when the written form is required only in order to create additional consequences. ${ }^{320}$ Thus, a contract for the lease of an immovable or part of it for a period exceeding one year should be made in writing. Such a contract, nevertheless, can be proved by witnesses, but in the case of the lack of a written contract, it will be considered as concluded for an indetermined period. ${ }^{321}$ In any case, evidence by witnesses or by the parties will be permitted if there is consent of both parties or when the accomplishment of the act in question is made probable by evidence in writing. ${ }^{322}$ This is similar to the "commencement of proof" requirement found, for example, in the Civil Code of Quebec. ${ }^{323}$

The court or the state arbitration commission (the latter applies only to disputes between state units) may admit evidence by witnesses or by the testimony of the parties if it considers it necessary because of the special circumstances of the case. ${ }^{324}$ Acts concerning rights, the value of which exceeds ten thousand zlotys, must be made in writing for evidence purposes. ${ }^{325}$ In cases of periodical payments, the value of payments during one year and in case of shorter periods, for the whole period, is taken into consideration for the purpose of the requirement of the written form ad probationem. ${ }^{326}$ Additions to, and modifications and cancellation of a written contract by consent of both parties must be proved in writing, as must withdrawal from such a contract. ${ }^{327}$ A written contract may be concluded by the exchange of writings signed by the parties. ${ }^{328}$ Power of attorney to take action requiring a written form must also be in written form. ${ }^{329}$ A general power of attorney must

\footnotetext{
${ }^{816}$ Art. 230 C.P. $\quad{ }^{317}$ Art. 232 C.P. $\quad{ }^{318}$ Art. 246 C.P.

${ }^{310}$ Art. 73, Civil Code [hereinafter cited as C.C.] of Apr. 23, I964 (r964 Dz. U. No. I6, item 93), in force on Jan. 1,1965 , according to art. I of the Law Introducing the Civil Code, of Apr. 23, 1964 (I964 Dz. U. No. I6, item 94).

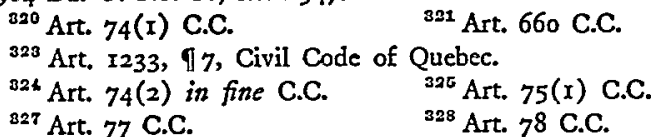
${ }^{322}$ Art. $72(2)$ C.C.$$
{ }^{326} \text { Art. 75(2) C.C. }
$$$$
{ }^{829} \text { Art. 99(I) C.C. }
$$ 
be in writing under sanction of nullity. ${ }^{330}$ The parties may agree that their specific acts must be in writing. In the absence of other provisions, it is considered that such a form is for evidence purposes only. ${ }^{331}$

Written form must be followed under pain of nullity in certain contracts such as (a) a pledge of movables left in the possession of the owner, in favor of a state bank; ${ }^{332}$ (b) a subrogation into the rights of the creditor with consent of the debtor as to the latter's consent; ${ }^{333}$ (c) a contract of transfer of debt and the consent of the creditor to the same; $;^{334}$ (d) a contract of production and delivery to a unit of the socialized economy producing agricultural goods $;^{335}$ (e) a guarantee for a debtor; ${ }^{330}$ and (f) a contract of commercial partnership. ${ }^{337}$ A contract of a civil law partnership must be made in writing for evidence purposes only; failure to comply with this requirement does not invalidate the contract. ${ }^{338}$

The requirement of the written form for evidence purposes does not apply to foreign trade. ${ }^{339}$ Provisions on commercial partnerships, limited liability companies, and stock companies (corporations) and some related provisions of the Commercial Code of June 27, I934, are maintained by the transitional law introducing the 1964 Civil Code. ${ }^{340}$ In practice, however, only a few such companies remain, shares in which are owned mostly by the state. New companies of this kind are no longer established. In certain cases and for certain contracts the notarial form is required under pain of nullity. ${ }^{341}$

In certain cases an official confirmation as to the date is required. ${ }^{342}$ Thus the pledge of non-tangible property (rights) must be backed up by a document with an officially confirmed date. ${ }^{343}$ The same applies to the sale where, after delivery of the thing sold to the purchaser, reservation of ownership is held by the seller until the payment of price. ${ }^{344}$ The date is considered to be confirmed (ascertained) when confirmed by an official document. After the death of a signatory, his signature must be similarly confirmed. ${ }^{345}$ Registration is required, for example, in the following cases: (a) notarial deeds-in notarial registers; (b) deeds involving real rights-in registers of immovables; (c) ownership and liens on sea-going vessels -in the register of ships; ${ }^{346}$ (d) cooperatives-in the register of cooperatives; $;^{347}$

\footnotetext{
${ }^{330}$ Art. 99 (2) C.C.

${ }^{333}$ Art. 518 C.C.

${ }^{331}$ Art. 76 C.C.

${ }^{334}$ Art. 522 C.C.

${ }^{332}$ Art. 308 C.C.

${ }^{336}$ Art. 876 C.C.

${ }^{337}$ Art. 77 of the Commercial Code of June 27, r934, I934 Dz. U. No. 57, item 502.

${ }^{338}$ Art. 860 C.C.

${ }^{330}$ Art. VI(2), Law Introducing the Civil Code, of Apr. $23,1964,1964$ Dz. U. No. 16, item 94.

${ }^{340}$ Art. VI, Law Introducing the 1964 Civil Code.

${ }^{341}$ Art. $73(2)$ C.C. Art. 80 C.C. (incapable of writing); art. 890 C.C. (donation except when performed); contract affecting real rights (on immovables), arts. 158, 236, 245 C.C.; salc of vcsscl or encumbrances of the same, arts. $65 \& 6 \mathrm{I}$ of the Maritime Code (196I Dz. U. No. 58, item 318); contract establishing a company with limited liability (art. I62, Commercial Code); contract establishing a stock company (art. 308, Commercial Code).

${ }^{342}$ Art. 8 I C.C.

${ }^{843}$ Art. 329 C.C.

34 Art. 590 C.C.

345 Art. 8I C.C.

${ }^{340}$ Decree of the Council of Ministers of Mar. II, Ig63, on the Register of Vessels, I963 Dz. U. No. Io, item 57 .

${ }^{347}$ Law on Cooperatives and Their Unions, of Feb. 17, 1961, 1961 Dz. U. No. 12 , item 61.
} 
(e) state enterprises-in the register of state enterprises; ; $^{348}$ ( $f$ ) deeds of mortgage in favor of a state bank-in the register kept by such a bank; and (g) commercial partnerships and companies-in the commercial register. ${ }^{349}$

There is no rule that evidence must be introduced before the judge rendering the decision in the matter, although this is done in most cases. Serious inconvenience or disproportionate costs justify the court in making an order to receive evidence by a delegated judge of this court or of another court. ${ }^{350}$

The party invoking evidence by witness must point out in detail the facts which have to be proved by each of the witnesses, and name the witnesses in order to enable the court to summon them. ${ }^{351} \mathrm{~A}$ co-defendant cannot be heard as a witness. ${ }^{352}$ The spouse, ascendants, descendants, brothers, sisters and persons linked by marriage in the same degree and persons linked by adoption with one of the parties may refuse to testify even after the dissolution of marriage or adoption. Such refusal is inadmissible in matters of civil status except in the case of divorce. ${ }^{353}$ A witness may refuse to answer questions when his answer could expose the above mentioned persons to penal responsibility, shame, or substantial and direct loss, or when such an answer would violate professional secrecy. A clergyman may refuse to answer questions concerning facts confided to him during confession. ${ }^{354}$ Witnesses are not sworn in and the religious cath is replaced by a "promise" as follows: "Aware of the meaning of my words and of my responsibility before the law, I promise solemnly that I will say only the truth, not concealing anything that is known to me."355 Minors below the age of seventeen years and persons condemned for perjury do not render this promise. Other persons may, by consent of the parties, be dispensed by the court from the declaration of promise. ${ }^{356}$

A witness first answers the chairman's question as to what he knows of the matter in question. Subsequently judges and parties may ask questions. A witness may request the reimbursement of necessary expenses connected with his appearance in court. Furthermore, he may request an indemnification for loss of earnings. The chairman of the court may grant to a witness an advance for the cost of travel and living expenses at the place of hearing. ${ }^{357}$ Witnesses who contradict one another may be confronted with each other. ${ }^{358}$

Parties may not be heard as witnesses. However, in cases where the evidence submitted does not elucidate facts essential for the decision of the court, the latter may order that parties be heard. ${ }^{359}$ Should it be impossible to hear all the parties for factual or legal reasons, the court will decide whether, under the circumstances, one party or neither should be heard. ${ }^{360}$ At first, parties are examined without the promise to tell the truth. Should such an examination fail to elucidate the facts, the court may order one of the parties to make the declaration of a promise to tell

\footnotetext{
${ }^{348}$ Decree on State Enterprises, of Oct. 26 , I950, I950 Dz. U. No. I8, item III.

${ }^{340}$ Art. VI(1), Law Introducing the 1964 Civil Code. Arts. 13-25, 79, r66, 330, Commercial Code.

350 Art. 235 C.P.

${ }^{361}$ Art. 258 C.P.

${ }^{853}$ Art. 26 I (I) C.P.

${ }^{354}$ Art. 26 I (2) C.P.

${ }^{307}$ Art. 277 C.P.

${ }^{350}$ Art. 267 C.P.

${ }^{300}$ Art. 302 C.P.
${ }_{302}$ Art. 259 , 14 , C.P.
${ }^{365}$ Art. 268 C.P.
${ }^{858}$ Art. 272 C.P.


the truth and examine such a party again. The testimony of one party after the declaration of such a promise does not exclude the examination of the second party, but on different facts. ${ }^{361}$ The party who testifies is warned about the penal responsibility for false testimony. ${ }^{322}$

\section{Remedies}

\section{Conservatory Measures}

No injunctions sensu stricto are available in Poland. The Code of Civil Procedure provides, however, for conservatory measures. In matters of claims within the jurisdiction of the courts or of a voluntary arbitration, a court may issue a temporary decree of conservatory measures when the claim appears credible and the lack of such conservatory measures might deprive the creditor of the enforcement of his rights in the future. Such conservatory measures may also be decreed in other cases where they are necessary in order to secure the execution of a court decision..$^{308}$ In matters not involving money claims, the court may decree appropriate measures. $^{364}$ The court's decision is rendered in a private sitting (in chambers) and served by the court on the creditor. Such a decision enjoins the creditor to perform or to refrain from performing a certain act or acts, or to abstain from hindering the creditor from performing a certain act or acts. ${ }^{365}$ The court may decree that an administrator be appointed for immovable property. The debtor cannot be appointed as such an administrator. ${ }^{368}$ Should the debtor disobey the order to refrain from certain acts or to abstain from hindering the creditor in the performance of certain acts, the court, on motion by the creditor and after hearing the parties, may fine the debtor. ${ }^{367}$ Furthermore, the court may decree that security be furnished by the debtor. ${ }^{368}$ Fines may be repeated. The change in status quo brought about by the debtor against the order of the court may be rectified and the objects restituted so as to restore the previous situation, all at the cost of the debtor. ${ }^{300}$ One fine cannot exceed 1,500 zlotys and the total of all fines cannot exceed 50,000 zlotys. $^{370}$ In case of non-payment of the fine within one week after the expiration of the deadline for appeal, the fine can be replaced by imprisonment at the rate of one day for 150 zlotys but the total imprisonment cannot exceed six months. ${ }^{371}$ The costs of imprisonment are paid by the debtor from his earnings. The creditor, however, must advance the money for such costs. ${ }^{372}$ When possible, the debtor shall be employed and remunerated during his imprisonment. ${ }^{373}$

Appeal from judgment in the first instance must be filed within two weeks after the service upon the appellant of the judgment stating reasons. After this period new grounds for revision (the term used in the Polish Code of Civil Pro-

\footnotetext{
${ }^{301}$ Art. 303 C.P.

${ }^{304}$ Art. 755 C.P.

${ }^{307}$ Art. I05I (I) C.P.

${ }^{370}$ Art. 1052 C.P.

${ }^{373}$ Art. 1056 (I) C.P.
}

${ }^{302}$ Art. 304 C.P.
${ }^{308}$ Art. 756 C.P.
${ }^{308}$ Art. 105 (2) C.P.
${ }^{371}$ Art. 1053 (I) C.P.

${ }^{303}$ Art. 730 C.P.
${ }^{800}$ Art. 757 C.P.
${ }^{300}$ Art. 1051 (3) C.P.
${ }^{372}$ Art. $1056(3)$ C.P. 
cedure for appeal) will not be admitted except for such grounds as are considered by the court ex officio (without a motion by a party). ${ }^{374}$ In the case where a party does not request a statement of the reasons within one week following the announcement of the judgment, the delay for appeal in revision (rewizja) starts on the day of the end of the period for the request of reasons. ${ }^{375}$ The appeal from other decisions of the court of first instance and from the orders of the chairman of the court is called in Polish zazalenie (literally, complaint). The complaint must be filed within one week after the service of the decision on the appellant, or, if the party did not make a request that the decision with reasons be served upon him, then within one week from the day when the decision was announced in court. ${ }^{376}$ The complaint must contain a short statement of the grounds for complaint including new facts and evidence, if any. ${ }^{377}$ The court of revision examines the complaint at a non-public session. ${ }^{378}$

\section{Specific Performance}

Courts may order specific performance. When the debtor (defendant) does not perform within the specified time, the creditor may claim damages. He may also apply to the proper court for authorization to perform the debtor's obligation at the debtor's cost. ${ }^{379}$ If the debtor acts in a manner prohibited by his obligation to refrain from certain acts, the creditor may claim damages and also apply to the proper court for authorization to remove, at the debtor's cost, whatever was done by the debtor contrary to his obligation. ${ }^{380}$ In urgent cases, the creditor may (while retaining his right to claim damages) perform the debtor's obligation or remove what the debtor did contrary to his obligation, at the debtor's cost, without obtaining an authorization by the court. ${ }^{381}$

The official entrusted with the enforcement of the decisions of the courts, who could be called bailiff although he acts only in matters of enforcement, will also execute non-money judgments. He will recover from the debtor the thing determined by the judgment and hand it over to the creditor. ${ }^{382}$ When the debtor is condemned to perform an act which cannot be performed by another person, then, upon the creditor's motion, the competent court, after hearing the parties, will fix a time limit within which he must execute the act ordered by the judgment. The court will also notify the debtor of the fine which he will have to pay if he fails to perform within the fixed time limit. ${ }^{383}$ When the creditor is bound to supply money or materials for such a specific performance, the enforcement will be started only after proof that he did supply them. ${ }^{384}$ Should the debtor fail to perform within the imposed delay, upon creditor's motion the court will impose the previously determined fine and at the same time fix a new deadline and a new higher fine. ${ }^{385}$
874 Art. 37 I (I) C.P.
377 Art. 394(3) C.P.
880 Art. 480 (2) C.C.
${ }^{375}$ Art. 37 r (2) C.P.
${ }^{378}$ Art. 397 (I) C.P.
${ }^{381}$ Art. $480(3)$ C.C.
${ }^{383}$ Art. 1050 (I) C.P.
${ }^{886}$ Art. $1050(2)$ C.P.
${ }^{878}$ Arts. $357(x) \& 394(2)$ C.P.
${ }^{379}$ Art. $480(x)$ C.C.
${ }^{892}$ Art. 104I C.P.
${ }^{585}$ Art. 1050 (3) C.P.




\section{Damages in Air Traffic Cases}

Poland is a party to the Warsaw Convention on Unification of Certain Rules of International Air Transportation, signed on October I2, I929, and to the Hague Protocol, signed on September 28, 1955. The Warsaw Convention limits the liability of an airline towards a passenger to one hundred twenty-five thousand francs in gold, corresponding roughly to $\$ 8,300.00,{ }^{388}$ and, for damages to his luggage, to the sum of 250 francs in gold, corresponding roughly to $\$ 16.60$ per kilogram, ${ }^{387}$ except where a special declaration was made at the moment of the registration of the luggage. This limit does not apply if the plaintiff can prove that the damage resulted from the transporter's wilful misconduct. ${ }^{388}$ The Hague Protocol doubled the limits of indemnity for damages to the person of the passenger. ${ }^{38 \theta}$ Furthermore the Hague Protocol added a new provision concerning court costs in favor of the plaintiff. ${ }^{390}$

\section{Enforcement of Human and Civil Rights}

The 1952 constitution of the Polish People's Republic declares that the Republic guarantees personal inviolability to its citizens. This statement does not cover other persons who are not citizens of the Polish People's Republic. According to the constitution, the liberty of a Polish citizen can be deprived only in specific cases determined by law. A Polish citizen detained by law must be liberated within fortyeight hours if a decision of a court or of an attorney of the state (prokurator) is not served upon him..$^{301}$ The Polish Code of Penal Procedure ${ }^{302}$ of March I9, 1928, as amended on December 2r, I955, and the new Polish Code of Penal Procedure of April $\mathrm{I} 9, \mathrm{I} 96 \mathrm{~g}^{393}$ in force since January $\mathrm{I}, 1970,{ }^{394}$ provide that a temporary detention may be imposed on a suspect by a court or a state attorney. The latter may use temporary detention only during investigation. ${ }^{395}$ Temporary detention may be imposed when (a) there is a justifiable reason to believe that the suspect will hide, try to influence witnesses to render false testimony, or hinder the penal proceedings in some other way; (b) the suspect has no permanent residence or defined sources of support or he cannot be identified; (c) the suspect has been convicted previously (recydywista); or (d) the offense in question is dangerous to society in a sub-

\footnotetext{
${ }^{388}$ Art. $22(I)$. $\quad{ }^{387}$ Art. 22(2). 388 Art. 25.

${ }^{380}$ Art. XI. The Protocol entered into force in Poland on August $x, 1963$.

${ }^{800}$ Art. 22, Warsaw Convention, added by art. XI, Hague Protocol.

301 Art. 74, Constitution.

${ }^{302}$ Amended text, $1956 \mathrm{Dz}$. U. No. 40, item 364, further amendments by Decree of Dec. 21, 1955, I955 Dz. U. No. 46, item 309; Law of June 18, 1959, r959 Dz. U. No. 36, item 229; Law of Mar, 28, 1958, $1958 \mathrm{Dz}$. U. No. 18, item 76.

${ }^{888} 1969 \mathrm{Dz}$. U. No. 13 , item 96 [hereinafter cited as N.C.P.P.; the predecessor to N.C.P.P. is hereinafter cited as C.P.P.].

${ }^{801}$ Art. I, An Act Introducing the Code of Penal Procedure, of Apr. 19, 1966, r969 Dz. U. No. 13, item 97.

${ }^{805}$ Art. I5x C.P.P., art. 210 N.C.P.P.
} 
stantial degree, a decision which takes into consideration the gravity of the offense or the proliferation of this type of offense. ${ }^{396}$ Temporary detention may also be applied during investigation when the offense is subject to a penalty of at least one year of imprisonment. ${ }^{397}$ The aim of a temporary detention is to prevent evasion of justice. ${ }^{398}$

Anybody has the right to detain a person caught in flagranti if it is feared that he will flee or if he cannot be identified. The detained must immediately be handed over the police (Citizens' Militia) or a state attorney. ${ }^{399}$ The police may detain a suspect when there are prerequisites for such a decision and if the suspect could flee or destroy evidence. ${ }^{400}$ Temporary detention during investigation cannot exceed three months but the provisional state attorney may extend it to six months. The Attorney General of the Polish People's Republic may extend the period of detention to nine months. The Supreme Court, on motion by the Attorney General, may further extend detention for a determined period when, due to the special circumstances of the case, investigation cannot be completed in nine months. ${ }^{401}$

The court or the state attorney (prosecutor) may abstain from arresting a suspect or may free him on bail by deposit or suretyship in a determined sum of money. The latter sum is determined according to the financial status of the accused and of the person furnishing the deposit or of the surety. ${ }^{402}$ The deposit may be made either by the accused or by another person. ${ }^{403}$ Such a deposit must be made in money or in securities acceptable as deposit by financial departments of the presidia of national councils (territorial offices of state administration). ${ }^{404}$ A registered mortgage may replace the deposit if accompanied by evidence that the value of the mortgaged property is sufficient to cover the sum of bail determined in the case. ${ }^{405}$ Suretyship may be supplied only by persons having permanent residence in Poland who furnish sufficient evidence that their property (sensu largo-not limited to immovables only) is sufficient to cover the sum of the bail. A surety may be refused when the person in question does not deserve confidence. ${ }^{406}$

\footnotetext{
${ }^{300}$ Art. $152(x)$ C.P.P., art. $217(2)$ N.C.P.P. (slightly different wording).

${ }^{307}$ Art. I52(2) C.P.P. Article 2I7(2) N.C.P.P. provides for a temporary arrest if the offense in question is subject to more than one year of deprivation of freedom. Such an arrest may be ordered when it is impossible to identify the accused.

${ }^{30 s}$ Art. 148 C.P.P. The new code provides only that all provisional measures "may be applied in order to secure the regularity of the procedure," art. 209 N.C.P.P.

${ }^{300}$ Art. 153 C.P.P., art. 205 N.C.P.P. $\quad{ }^{100}$ Art. $x_{54}$ C.P.P., art. 206 N.C.P.P.

${ }^{101}$ Art. 158 C.P.P., art. 222 N.C.P.P. The new code provides that the provincial state attorney cannot extend the temporary arrest beyond six months. He may, however, petition the provincial court to extend the period of the temporary arrest for another determined period, the length of which is not limited in the code, if such period is indispensable for the completion of the investigation.

${ }^{602}$ Art. 159 C.P.P., art. 225 N.C.P.P. $\quad{ }^{103}$ Art. I6I C.P.P., art. 226 (I) N.C.P.P.

${ }^{104}$ Art. 162 C.P.P. Article 226 (2) N.C.P.P. leaves to the court the determination of the security and its conditions. Security may be furnished in money, negotiable effects (bonds, etc.), by pledge, and hypothec.

${ }^{205}$ Art. 163 C.P.P.

${ }^{100}$ Art. I64 C.P.P. Article 232 N.C.P.P. requires that the person furnishing the suretyship be "worthy of confidence" and omits the previous requirement of permanent residence in Poland.
} 
Notwithstanding the deposit or suretyship, the court or the state attorney (prosecutor) may order the arrest of the accused when new circumstances require it. ${ }^{407}$

The court or the state attorney (prosecutor) may prohibit the accused to leave the place of his permanent residence or may put him under surveillance by the police or the territorial national council or other authority. In case of surveillance the accused must report periodically to the supervising authority according to the decision of the court or the state attorney. The state attorney, during investigation, and the court at the start of court proceedings, may lift this restriction. ${ }^{408}$

Decisions on temporary measures, detention, bail, prohibition to leave the place of permanent residence, and surveillance are subject to appeal. ${ }^{400}$ Such appeal is to the court of second instance only, its decision being final. ${ }^{410}$ Appeals from decisions of the state attorney (prosecutor) during investigation are decided by the superior state attorney. ${ }^{411}$ Appeals from decisions of the police during investigation are decided by the state attorney supervising such an investigation. ${ }^{412}$ Appeals from decisions of the court in these matters are heard by the higher court in private session. ${ }^{413}$ The appeal does not suspend the decision being appealed, but the authority which rendered it may suspend its execution. ${ }^{414}$ Appeals must be lodged within seven days, ${ }^{415}$ except appeals against unjustified arrest which may be lodged at any time. ${ }^{416}$ The time limit starts on the day when the decision being appealed was announced, or when, according to law such decision must be served, on the date of service. ${ }^{417}$

\section{Political and Economic Factors}

In the wake of World War II, Poland was left in the sphere of influence of the U.S.S.R. This caused basic political and economic changes in Poland, which became one of the East European states of the so-called "people's democracy."18 Its economy is based on socialized means of production, exchange, communications, and credit. The economic and cultural life of the nation is developed according to the national economic plan, especially through the extension of the state socialist

${ }^{107}$ Art. I70 C.P.P. This provision is not repeated in the new code.

${ }^{108}$ Art. I73 C.P.P., art. 235 N.C.P.P. The wording of the new provision is less detailed.

${ }^{100}$ Art. I50 C.P.P., art. 212 N.C.P.P.

${ }^{410}$ Art. 353(3) C.P.P. Article 212 N.C.P.P. adds that an appeal from the decision of the state attorney ordering a temporary arrest lies to the competent court. There is no appeal from the decision of a court ordering a temporary arrest.

111 Art. 354(2) C.P.P.; art. 413 N.C.P.P., especially (2).

${ }^{413}$ Art. 354 (2) C.P.P., art. 4r3(3) N.C.P.P.

113 Art 358 C.P.P.

114 Art. 357 C.P.P., art. 4 II N.C.P.P.

115 Art. 208(I) C.P.P. Article 4I0 N.C.P.P. adds that it starts on the day of announcement of the decision, except when the law requires the service upon the party in question; in the latter case the delay starts on the day of such service.

${ }^{118}$ Art. $208(2)$ C.P.P. The rg69 code does not repeat this provision.

${ }^{117}$ Art. 209 C.P.P., art. 410 N.C.P.P.

${ }^{418}$ Art. I, Constitution of the Polish People's Republic, of July 22, 1952, I952 Dz. U. No. 45, item 304 
industry. ${ }^{419}$ Mineral resources, waters, state forests, mines, roads, railways, water and air transportation, media of communication, banks, state industrial enterprises, state agricultural enterprises and machine stations, state commercial enterprises, and municipal enterprises and installations are the property of the nation and subject to special care and protection. ${ }^{420}$ The state has a monopoly in foreign trade. $^{421}$ In practice, only small workshops and commercial stores are allowed to stay in private ownership. While larger agricultural properties, exceeding fifty hectares, have been nationalized (not the surplus over fifty hectares but the entire property), eighty-five per cent of the agricultural land is privately owned by small landowner-peasants. In cases of acquisition in any manner, including succession, of an agricultural land exceeding fifteen hectares, or in cases of agricultural farms exceeding twenty hectares, the surplus may be taken over by the state. ${ }^{422}$ Moreover, the new owner must be qualified to manage a farming unit, either by a diploma from an agricultural school or by a certificate issued by the local national council (office of the territorial state administration). ${ }^{423}$ Otherwise he is unable to hold agricultural property.

Subordination of the private economic sector to the overall national economic plan, including prices fixed by the state and control of sources of supply of raw materials and a taxation policy leaning heavily on private enterprise, makes its future in Poland precarious. This obviously also applies to aliens. International trade relations are maintained through state licensed state enterprises which generally act according to the customs and usages of international trade. Houses in certain large cities have been nationalized. Rents in private houses situated in the majority of cities and towns are fixed by state authorities, who also control accommodations and renting. The owner is not allowed to rent an apartment in his house to a tenant of his choice without a permit from the local territorial state administration office.

\section{CONCLUSION}

\section{A. Constitution}

The 1952 constitution of the Polish People's Republic does not guarantee rights to foreigners. Chapter 7 of the constitution, entitled "fundamental rights and duties of citizens," subdivided into 23 articles, ${ }^{424}$ deals exclusively with the citizens of the Polish People's Republic, except article 75 which declares that the Polish People's Republic grants asylum to citizens of other states persecuted in consequence of their defense of the interests of working masses, their struggle for social progress, their activities in defense of peace, and their struggle for national liberation or scientific activities.

\footnotetext{
${ }^{410}$ Id. art. $7(1) . \quad \quad{ }^{420} I d$. art. 8. $\quad{ }^{221} I d$, art. $7(2)$.

${ }^{32}$ Art. 6(I), Decree of the Council of Ministers of Nov. 24, 1964, on Transfers of Ownership of Agricultural Immovables and Successions Relating Thereto, I964 Dz. U. No. 45, item 304 .

${ }^{423}$ Id. art. 3 .

224 Arts. 57-79, Constitution.
} 


\section{B. Private International Law}

The Polish private international law of November 12, 1965, ${ }^{425}$ provided that foreigners have rights and obligations in Poland on an equal basis with Polish citizens, except when otherwise provided by law. Thus the rights of foreigners in Poland are subject to (a) limitations or restrictions resulting from the political and socio-economic structure of the Polish People's Republic, such limitations or restrictions being applicable to Polish and non-Polish citizens alike, (b) limitations or restrictions expressly defined in legal texts and applicable to foreigners only, and (c) the condition of reciprocity.

\section{Limitations and Restrictions Applicable to Both Aliens and Nationals}

The limitations and restrictions applicable to Polish citizens and foreigners alike concern in the first place foreign property rights in Poland. Such property rights are subject to general nationalization measures and also to other limitations, affecting for instance housing and dwellings. Other restrictions affect rights of inheritance as regards farms in Poland, by persons, including foreigners with no agricultural education or practice.

In the procedural domain, certain provisions may in practice affect more seriously foreigners residing far away from the proper court in Poland than Polish citizens residing in its district. For example, geographical separation gives special significance to a time limit of only one or two weeks for filing an appeal. The provisions of the Code of Penal Procedure allow the state attorney to keep a suspect under arrest for three, six, or nine months, or for even longer periods during the preliminary investigation directed by him. The fact that such suspects have the right to appeal only to the next superior state attorney does not constitute sufficient protection of their rights.

Foreign law may be applied in Poland in certain cases, provided by Polish private international law, except when such application would be contrary to the fundamental principles of the legal order of the Polish People's Republic. ${ }^{420}$ This does not mean, however, that the application in Poland of lex patriae to a private (non-state) foreign bank is inadmissible in Poland, although it is against the Polish constitution that a bank be owned by individual shareholders and not by the state. ${ }^{427}$ The system of a centrally planned and directed economy, especially the state monopoly of foreign trade, limits the choice of foreigners as to contracting parties in Poland and as to prices of goods. ${ }^{428}$ The licensing system which restricts payment in foreign currencies and the transfer of capital abroad, applicable to Polish citizens and foreigners alike, makes it practically impossible to receive payments due to foreigners residing outside Poland. In practice, payments resulting from the trade of the Polish state enterprises with foreign traders are authorized.

\footnotetext{
${ }^{425}$ Art. 8, I965 Dz. U. No. 46 , item 290.

${ }^{127}$ Art. 8, Constitution of 1952.
}

${ }^{126} I d$. art. 6.

${ }^{428}$ Art. $7(x)$ \& (2), Constitution. 


\section{Restrictions Directed Specifically to Aliens}

Restrictions in the procedural field, directed specifically at foreigners, are sometimes aggravated by the general provisions applicable to both Polish citizens and aliens. For example, the deposit of security for costs by an alien calls for the conversion of his currency into Polish currency according to a rate of exchange established by the Polish authorities. This official rate of exchange strikingly reduces the free market value of such foreign currency as can be seen in a comparison of the differences between various official Polish rates of exchange, such as, for example, the tourist rate of exchange, 24 zlotys to one U.S. dollar and the Polish state enterprise P.K.O. rate of exchange of approximately 70 zlotys to one dollar.

\section{E. Reciprocity}

The condition of reciprocity seriously curtails the procedural rights of aliens of numerous states as to security for costs requirements, ${ }^{429}$ suits in forma pauperis, ${ }^{430}$ appearance by foreign counsel, ${ }^{431}$ international judicial cooperation, ${ }^{\mathbf{4 3 2}}$ inheritances left by foreigners, ${ }^{433}$ recognition of foreign judgments, ${ }^{434}$ and the enforcement of foreign judgments granting alimony. ${ }^{435}$ Other foreign judgments and arbitral awards are enforceable in Poland only according to international treaties. ${ }^{436}$

\section{F. International Agreements}

The provisions of international treaties to which Poland is a party supersede the corresponding provisions of Polish laws. ${ }^{437}$

\section{G. International Trade}

Polish legislators decided to maintain, in practice, the unity of law governing relations (a) between state units, (b) between state units and other Polish parties, and (c) between the Polish parties and foreigners. ${ }^{438}$ They decided also to abolish the division of Polish law into civil law and commercial law, and the new civil code of April 23, I964, ${ }^{430}$ replaced both the previous commercial code ${ }^{440}$ and several

\footnotetext{
$\$ 20$ Arts. III9 \& $x 120$, II I, C.P.P.

${ }^{430}$ Art. II29 C.P.P.

131 Art. III 8 C.P.P.

${ }^{432}$ Art. $\operatorname{II}_{3}$ (2), 13 , C.P.P.

${ }^{433}$ Arts. II39(2) \& II 4 I C.P.P.

134 Art. II 46 C.P.P.
}

${ }^{\triangle 85}$ Art. II5O(3) C.P.P.

${ }^{430}$ Art. II5O(I) C.P.P.; as to awards, art. II50(2) C.P.P.

${ }^{437}$ Art. rog6 C.P.P. Art. I(2), Polish Private International Law, of Nov. I2, 1965, 1965 Dz. U. No. 46, item 290.

${ }^{438}$ Wasilkowski, Le projet du code civil polonais, RAPPORTS POLONAIS PRÉSENTÉs AU SIXIÈME CONGRÈS INTERNATIONAL DE DROIT COMPARE 199 (I962). See also J. JAKUBOWSKI, UMOWA SPRZEDAZY W haNdLU MIEDzXNarodowym; Metody I formy regulacji (Contract of Sale in International Trade; Methods aNd Forms of Regulation) 26I-7I (I966) [hereinafter cited as UMOWA SPRZEDazY]; St. Piatowski (chairman of the study group), Baginski, Grzybowski, Ignatowicz, Stelmachowski, \& Wengerck, Prawo cywilne w XX-leciu PRL (Civil Law During 20 Years of the Polish People's Republic), 1965 Studia Prawnicze No. 9, at 44 f. (especially at 60) (report submitted and discussed at the session of the committee and institute of juridical sciences of the Polish Academy of Sciences in commemoration of twenty years of existence of the Polish People's Republic, Nov. 29-30, 1964).

${ }^{30}{ }^{306} 4 \mathrm{Dz}$. U. No. 16 , item 93 .

${ }^{100}$ Commercial Code of June 27, I934, I934 Dz. U. No. 57, item 502. 
civil law acts. ${ }^{441}$ Nevertheless, some provisions of the commercial code, governing the few remaining commercial partnerships, limited liability companies, and stock capital corporations, were maintained in force, including provisions on the commercial register. ${ }^{442}$ Polish legislators did not follow the example of Czechoslovakia, where the special law of December 4, Ig63, applicable to international trade exclusively, has been in force since April I, $1964^{443}$

At the same time, some provisions of Polish law, introducing the new civil code, contain special provisions for the international trade. ${ }^{444}$ Requirements of the written form for the purposes of evidence do not apply to foreign trade transactions. ${ }^{44 \sigma}$ Exclusion or limitation of liability for the defects of saleable objects, except in cases where the vendor fraudulently concealed such defects, is allowed in foreign trade. ${ }^{406}$ Rights of retention in relations between traders, according to the 1934 commercial code, ${ }^{447}$ was maintained for the foreign trade. ${ }^{488}$ The agreed liquidated damages in cases concerning foreign trade relations are not subject to modification by the courts. ${ }^{499}$ Parties may submit their contract to the law of the state chosen by them, provided that the law in such a state is related to the contract. ${ }^{460}$

The 1964 Polish civil code did not repeat the provisions of the previous code of obligations, ${ }^{451}$ which stated that the parties could shape their contract according to their wish provided that the contents and aim of such contract were not contrary to the public order, statutes and good morals. ${ }^{452}$ It is argued that the 1964 civil code managed, nevertheless, to maintain freedom of contract, and that it is possible to enter into contracts not described in the code. Such a contract is valid unless it is contrary to a statute (law) or if its aim is to achieve a result prohibited by law. ${ }^{453}$ Others express the opinion that, whatever the position of the principle of freedom to contract in internal Polish relations, such a freedom must be applied to international trade. ${ }^{454}$ According to the maritime code of $196 \mathrm{I}$, the parties, subject to

\footnotetext{
"\$1 Art. III, Law Introducing the 1964 Civil Code.

${ }^{42}$ Art. VI, Law Introducing the 1964 Civil Code.

"48 Code of International Trade of Dec. 4, I963; Law No. Ior of the Collection of Laws of the Socialist Republic of Czechoslovakia, published Dec. 18, 1963 , in force on Apr. I, I964. See Kalensky \& Kopac, The New Czechoslovak Code of International Trade, I964 BuLletin of Czechoslovak Law Nos. $3-4$, at 145 ff; English text at Igr $f$.
14 Art. VI(2) \& (3).
4.5 Art. VI(2).

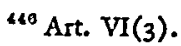

\$47 Arts. 518-24.

${ }^{48}$ Art. VI(2), Law Introducing the 1964 Civil Code.

*9 Art 531, Commercial Code; Art. VI(2), Law Introducing the 1964 Civil Code.

${ }^{450}$ Art. 6, Polish Private International Law, of Nov. $\mathrm{I}_{2}, 1965$, 1965 Dz. U. No. 46, item 290.

${ }^{451}$ Code of Obligations, of Oct. $27,1933,1933$ Dz. U. No. 82, item 598 . The subsequent amendments did not change these provisions.

${ }^{452}$ Id. art. 55 .

${ }^{463}$ Art. 58(x), 1964 Civil Code of Apr. $23,1964,1964$ Dz. U. No. 16, item 93. Before the entry in force of the $I 964$ Civil Code on Jan. $x, x 965$, there was no comprehensive civil code in Poland but several laws dealing with various branches of civil law: general part, law on rights in rem, successions, code of obligations, etc. Przymusinski, Kodeks cywilny a miedzynarodowy obrot handlosyy, I965 Przeglad Ustawodawstwa Gospodarczego, pt. I, at 67 .

I5A UMOWA SPRZEDAZY 262.
} 
exceptions provided by statutes, may regulate their relationship in their contract according to their wish. ${ }^{455}$ In international relations, freedom of contract may be achieved by the choice of a law connected with the contract and providing for such freedom of contract. ${ }^{456}$ In internal relations in Poland, limitations on the freedom to contract result from the principle that the provisions of civil law shall be interpreted and applied in conformity with the principle of the structure and aims of the Polish People's Republic. ${ }^{457}$ A legal act contrary to the statute (law) or aiming at a result prohibited by law (détournement de la loi) is void. ${ }^{458}$ This is also the case when a legal act is contrary to the principles of socialist life. ${ }^{459}$

According to several Polish authors, the unity of the Polish civil code, applicable in principle to the units of the socialized economy, to other Polish persons, and, according to the rules of private international law, to foreigners, including the relations of international trade (except special rules mentioned explicitly in the code) calls for an interpretation which excludes application to international trade or provisions meant for the internal Polish situation. Thus an opinion has been advanced that the requirement that legal acts must conform with the principles of socialist life in Poland ${ }^{480}$ is not a part of the national trade system. ${ }^{461}$ An opinion was also expressed, however, that these principles, interpreted as a requirement of good faith, may apply to international trade. ${ }^{462}$ It is maintained that the provisions allowing for the elimination of an agreed price and its replacement by an officially fixed price, ${ }^{463}$ has no place in international trade. ${ }^{464}$ Also the provisions on a maximum price, ${ }^{465}$ a minimum price, ${ }^{468}$ and on the adjustments resulting therefrom ${ }^{467}$ are, according to one author, inapplicable to the international trade. ${ }^{468}$ This author also warns that the provisions which allow a court or arbitration commission to disregard a statute of limitation if it does not exceed three years and if the delay in the institution of proceedings is justified by exceptional circumstances $^{469}$ could be considered as being contrary to the security of international commerce and to the principle pacta sunt servanda. ${ }^{470}$

In the final analysis, the answers to all these problems will be provided by the courts, especially the Court of Arbitration at the Polish Chamber of Foreign Trade, and the International Court for Maritime and Inland Navigation at Gdynia. ${ }^{471}$

\footnotetext{
${ }^{406}$ Art. 2, Maritime Code. J. Lopuski \& R. Adansmi, Polish Maritime Code I4 (1964); J. Sxapski, AUTONOMIA WOLI W PRAWIE MIEDZYNARODOWYM PRYWATNYM W ZAKRESIE ZOBOWIAZAN A UMOW 73 (I964). ${ }^{106}$ Art. 25, Polish Private International Law, of Nov. I2, 1965, I965 Dz. U. No. 46 , item 290 , in force on July $x$, rg66 (according to its art. 38 ). ${ }^{457}$ Art. 2 C.C.

${ }^{950}$ Art. 58(2) C.C. See W. Czachorski, Prawo Zobowiazan w Zaryste (Outline of the LaW of Obligations) I95 (rg68).

${ }^{100}$ Art. 5 C.C.

${ }^{101}$ Przymusinski, supra note 453, at 66. (Przymusinski was one of two reporters of the draft civil code at the Section of Law and Arbitration Policy at the Polish Chamber of Foreign Trade.)
"03 UMOWA SPRZEDAZY 263.
${ }^{100}$ Art. 538 C.C.
4 Art. 537 C.C.
${ }^{168}$ Art. 539 C.C.
${ }^{68}$ UMOWA SPRZEDAZY 264.
${ }^{169}$ Art. Ir7(3) C.C.
44 UMOWA SPRZEDAZY $26_{4}$.
${ }^{187}$ Arts. 534-42 C.C.
${ }^{470}$ UMOWA SPRZEDAZY 264.

${ }^{471}$ See notes 131 and 167 supra.
} 


\section{Appendix \\ International Agreements Related to Procedure to Which Poland is a Party}

\section{Multilateral Conventions Related to Procedure}

A. The Hague Conference of Private International Law

(I) On the conflicts of laws as to marriage, of June 12, rgo2.

(2) On the conflicts of laws and of jurisdictions as to divorce and separation from bed and board, of June I2, I902 (denunciation in I969).

(3) On the conflicts of laws as to the effects of marriage on rights and obligations of spouses in their personal and property relations, of July 17 , Ig05 (denunciation in $\mathrm{rg} 69$ ).

(4) On protection of minors, of June 12 , $x 902$.

(5) On interdiction, of July 17, I905.

(6) On civil procedure, of July I7, I905 (at present in force only in relations with Iceland).

(7) On civil procedure, of March I, I954 (in force since I963).

(8) On the conflicts of laws relating to the form of testamentary dispositions, of October 5, Ig6r (ratified in I969).

B. Other Multilateral Conventions

(I) Convention of Paris on industrial property, of March 20, r883, with modifications of Brussels of December 14, I900, of Washington of June 2, I9II, of the Hague of November 6, I925.

(2) Madrid agreement of April I4, Ig6I on the registration of industrial and commercial trademarks, with modifications of Washington, of July 2, rgII and of the Hague, of November 6, rg25.

(3) Warsaw convention on air transport, of October I2, I929, with modifications by the Hague Protocol of September 28, 1955 .

(4) Bern convention on copyright, of September 9, 1886 , with modifications of Berlin of November 13, rgo8 and of Rome of June 2, I928.

(5) Geneva convention on conflicts of laws as to bills of exchange and promissory notes, of June 7 , I930.

(6) Geneva convention on conflicts of laws as to cheques, of March I9, I931.

(7) Bern conventions on railway transports (CIM and CIV) of February 25, Ig6r (including additional protocols).

(8) Vienna conventions on diplomatic relations, of April r8, r96r.

(9) New York convention on alimentary claims abroad, of June 20, I956.

(Io) Geneva Protocol on arbitration clauses of September 24, I923.

(II) New York convention on recognition and enforcement of foreign arbitral awards, of June ro, 1958. 
(I2) Geneva European convention on international commercial arbitration, of April 2I, Ig6r.

(13) Five conventions of Brussels on maritime law.

\section{Bilateral Agreements}

A. Agreements on legal assistance and legal relations in civil, family, and penal matters

(I) Czechoslovakia, of July 4, Ig6r.

(2) Bulgaria, of December 4, 196r.

(3) Yugoslavia, of February 6, rg60.

(4) German Democratic Republic (East Germany) of February I, I957.

(5) Rumania, of January 25, I962.

(6) Hungary, of March 6, I959.

(7) U.S.S.R., of December 28, 1957.

(8) France, on law applicable, jurisdiction and enforcement of decisions in personal and family law, of April 5, I96\%.

(9) France, on the facilitation of the application of the Hague convention on civil procedure of March I, I954, signed on April 5, I967.

(Io) Great Britain on legal proceedings in civil and commercial matters, of August 26, т93.

(II) Canada, convention on legal proceedings in civil and commercial matters with Great Britain of August 26, 193r, extended to the PolishCanadian relations, on July 23 , 1935 .

B. Consular agreements on extradition and assistance in penal matters

(r) Belgium, of June 12 , 1928.

(2) France, of December 30, I925.

(3) Italy, of July xo, I935.

(4) Bulgaria, of September I9, Ig6r.

(5) Czechoslovakia, of May I7, Ig60.

(6) Yugoslavia, of November I7, 1958 .

(7) German Democratic Republic (East Germany), of November 25, 1957.

(8) Rumania, of October 5, 1962.

(9) Hungary, of May 20, I959.

(Io) U.S.S.R., of January $2 \mathrm{I}$, 1958. 